\title{
IPO Pricing and the Relative Importance of Investor Sentiment - Evidence from Germany*
}

\author{
Andreas Oehler ${ }^{\mathrm{a}}$ / Marco Rummer ${ }^{\mathrm{a}}$ / Peter N. Smith \\ ${ }^{a}$ Department of Economics and Management, Bamberg University, Germany \\ ${ }^{\mathbf{b}}$ Department of Economics and Related Studies, University of York, UK
}

Revised Version, March 2004

\begin{abstract}
:
Wasserfallen and Wittleder (1994), and Ljungqvist (1997) examined the well established underpricing phenomenon for the German stock market and found that mainly ex-ante uncertainty drives the degree of underpricing for 1961-1987 and 1970-1993, respectively. This paper focuses on German IPOs during the 1997 to 2001 period and covers a sample of 410 firms. The average initial return amounts to $44.47 \%$ and peaks with $64.10 \%$ in 1998 . Using time series regressions the cyclical behaviour of the issue activity is examined and we report that lagged underpricing and IPO volume influence the decision to go public by using a VAR(4). Following Ruud (1993), indirect evidence for the existence of price stabilisation is reported by analyzing the initial return distribution and the greenshoe usage. The cross-sectional regression using both OLS- and censored date estimations shows that the initial returns are mainly driven by investor sentiment and demand, and less by ex-ante uncertainty, especially during the dot-com boom.
\end{abstract}

JEL Classification: G10, G12, G24, G32

Key Words: Initial Public Offerings (IPO), Underpricing, Investor Sentiment, Hot-issue Markets, Price Support, Ex-ante Uncertainty

* Corresponding to. Andreas Oehler, Marco Rummer, Bamberg University, Chair of Finance, Kirschaeckerstr. 39, D-96045 Bamberg, phone: (+49) 951-863-2536, fax: (+49) 951-863-2538, e-mail: finanz@sowi.uni-bamberg.de, internet: http://www.unibamberg.de/sowi/finanz.

The paper benefited from discussions with James Gill, Leslie Godfrey, John Hutton, Aydin Ozkan, and Ben Warner. We particularly thank Angelica Gonzales for valuable comments on a previous version. We received also helpful comments from Dirk Schiefer and Oliver Schwindler. The authors are grateful to Stefan Günther, Nils Nawroth, and Philipp Federspieler for technical support. The usual disclaimer applies. 


\section{$1 \quad$ Introduction}

Since the early 1970s, a huge and systematic increase from the offer price of an initial public offering (IPO, hereafter) in the primary market to its first-day (closing) price in the secondary market was documented (for the first research, see Stoll and Curley (1970), Logue (1973), Reilly (1973), Ibbotson (1975)). From an issuer's point of view this phenomenon is usually called underpricingA growing body of studies tried to explain the underpricing phenomenon and found in all countries that IPOs of operating companies are underpriced, on average (for an exhaustive survey, see Ritter (1998) and (2003), Brounen and Eichholtz (2002)).

Stimulated by the remarks in Ma and Tsai (2001), the classification issues in Ritter and Welch (2002), and time-variation in IPO-puzzle patterns ${ }^{1}$, especially the hype at the end of the 1990s (for example, see Loughran and Ritter (2003)), we aim to sharpen the distinction between the IPO valuation and information problems in setting the offer price on the one hand ${ }^{2}$ and the allocation-, demand-, or trading-related determinants on the other hand ${ }^{3}$.

Following Ma and Tsai, a distinction needs to be made between the initial return (as defined above) and an IPO discount which is the difference between the offer price and what an issuer could has been achieved without discount, i.e., the initial return only if the secondary market prices the shares efficiently. By classifying the theories, models and other determinants of underpricing in the huge and steadily growing body of IPO literature, we derive valuation- and information-related components and demand- and sentiment-related variables, including the dynamics of the IPO-market cycle.

Our empirical work therefore attempts to quantify the relative importance of the different explanations in one study. In contrast to other studies which concentrate on more traditional determinants or only choose a selective view or cannot include the late 1999/2001 period ${ }^{4}$, we focus on the German market using a newly configurated and corrected data set with 410 IPOs for the 1997-2001. We analyze the importance of both the offer-price-related and the market-related variables (e.g. hot-issue, price support, investor sentiment).

\footnotetext{
${ }^{1}$ I.e., issuing activity, underpricing, aftermarket trading.

2 I.e., asymmetric information, adverse selection, ex-ante uncertainty.

${ }^{3}$ I.e., hot markets; investor sentiment (ignoring the risk-return trade off, beliefs unwarranted by fundamental values, overreaction, overoptimism, overconfidence, self attribution); behavioral aspects of underwriters and issuers ("leaving money on the table"); aftermarket trading.

${ }^{4}$ For example, see Wasserfallen and Wittleder (1994), Ljungqvist (1997), Aggarwal and Leal (1998), Löffler (2000), Sapusek (2000), Stehle, Erhardt, and Przyborowsky (2000), Hunger (2003), and Burghof and Hunger (2004).
} 
To untwist what really drives IPO underpricing we first analyze the cyclical behavior of the issue activity (i.e. IPO volume) and underpricing. Consistent with Lowry and Schwert (2002), we find that issue activity is influenced by past IPO volume and underpricing. As price support truncates the distribution of underpricing and, therefore, influences the cross-section analysis quite substantially we analyze this phenomenon using Ruud's (1993) methodology and find evidence of underwriters stabilizing new issues. Combining all this, we analyze 410 IPOs during 1997 till 2001 using both OLS and censored data estimation methods. On the one hand, we use valuation- and information-related components like the length of the subscription period and width of the bookbuilding range and on the other hand demand- and sentiment-related variables like the past issue activity, return of the 'Nemax All Share' index or the usage of the greenshoe. Summing up, we conclude that underpricing is mainly influenced by investor sentiment and, therefore, by the demand of potential investors, and less by exante uncertainty, especially during the dot-com boom.

The paper is organized as follows. Section 2 sheds some light on theoretical aspects and selected previous research and presents our hypotheses that motivate the data analysis. Section 3 describes the data set. Section 4 describes the firm characteristics and presents results on industry groups' impact, market segmentation, dynamics of the IPO cycle, and price support. Section 5 combines our variables in different cross-section regressions and Section 6 concludes.

\section{Theory, Related Research and Hypotheses}

\subsection{Theory and Related Research}

Ritter and Welch (2002) summarize the valuation- and information-related topics of the traditional analyses of the underpricing phenomenon as follows: “... the solution to the underpricing puzzle has to lie in focusing on the setting of the offer price, where the normal interplay of supply and demand is suppressed by the underwriter." Therefore, they stress the characteristics of a primary or contract market under asymmetric information.

Asymmetric information uncertainty arises from the fact that both the issuer or underwriter (if there are no agency conflicts between them) is better informed than investors and vice versa. This uncertainty generates adverse selection and signaling problems: high-quality issuers can afford to sell their shares at a lower price, i.e., leave money on the table, because they trust in future issuing activity and analyst coverage (see Welch (1989), Chemmanur (1993)). The latter means that the issuer or underwriter faces a placement problem. Under the realistic assumption that investors are differentially informed (and consequently the issuers or underwriters), they fear a winner's curse (see Rock (1986), 
Koh and Walter (1989)) or a (negative) informational cascade as investors judge the sentiment or interest of other investors (see Welch (1992), Amihud, Hauser, and Kirsh (2003)).

Other explanations of underpricing of this type include in this range like the traditional information-gathering perspective of bookbuilding, i.e., information revelation during the road show (see Benveniste and Spindt (1989), Benveniste and Wilhelm (1990), Spatt and Srivastava (1991)) and the filing period (see Hanley (1993), Lee, Taylor, and Walter (1999), Cornelli and Goldreich (2001, 2002)), seem incapable of explaining the measured magnitude of underpricing (see Ritter and Welch (2002)).

Despite this, it is interesting to introduce the length of the subscription period and the width of the bookbuilding range as signals of IPO quality to investors (see below, 2.2). An additional demand-related explanation for underpricing refer to the costs of going public in general.

Habib and Ljungqvist (2001) document empirical results that suggest underpricing can be interpreted as a necessary cost component of going public and therefore can be interpreted as a partial substitute for marketing expenditures. Ritter and Welch (2002) argue against this view as it cannot plausibly explain the severe underpricing during the IPO or Internet bubble some years ago. They cannot believe that an underwriter could not have easily placed shares with half the degree of underpricing observed. We think that this critique is true for a descending but not for an increasing market where investors definitively expected large underpricing. If IPOs are underpriced on average, investors have an incentive to discern which will be underpriced most (see Sherman and Titman (2002)). In other words, high underpricing stimulates stronger issuing activity of companies with different quality (for example, see Loughran and Ritter (1995)), while increasing underpricing tends to be an instrument in cold issuing periods. Furthermore, on the supply side the change in the issuer objective function may work in the same direction, i.e., issuing firms increasingly acquiesced in leaving money on the table (see Ljungqvist and Wilhelm (2003), Loughran and Ritter (2003)).

Concentrating on (secondary) market-related variables while taking bounded rationality and the role of investor sentiment into consideration for explaining the price behavior of IPO stocks, the literature offers a couple of results, but no consensus.

Krigman, Shaw, and Womack (1999) document a positive correlation between the magnitude of underpricing and aftermarket trading. The trading volume in the secondary market is higher, the greater the underpricing is (for related evidence, see Ellis, Michaely, and O'Hara (2000), Boehmer and Fishe (2001)).

Loughran and Ritter (2002) explore the agency conflict between issuer and underwriter and use prospect theory to explain that the greater the recent increase in issuer's wealth, the less is the bargaining effort in negotiations with the underwriter over the offer price. One answer to the question of why issuers do not choose a more efficient selling mechanism like auctions (for example, see Biais 
and Faugeron (2002)) is the spinning or corruption hypothesis introduced by Loughran and Ritter (2002) (see also the evidence presented in Klein and Zoeller (2003)). Additionally, Bradley and Jordan (2002) and Lowry and Schwert (2002) document results that when the overall stock market rally underwriters do not fully adjust the offer price. Based on the prospect theory explanation it follows that the only partial adjustment ends in a higher underpricing (offer prices are not raised as much as they could have been in the demand scenario). Furthermore, Ljungqvist, Nanda, and Singh (2003) demonstrate results that the sluggish adjustment of the offer price is driven by the difference in opinion between rational and sentiment investors.

Another part of the literature focuses on climate effects and growing investor sentiment. The initial price run-up (and subsequent underperformance) is more excessive in "hot" periods of high IPO volume. Ritter $(1984,1991,1998)$ documents that cycles exist in both the volume and the average underpricing of IPOs (see also Ibbotson and Jaffe (1975)). Periods of high average initial returns and rising volume of IPOs are known as "hot issue" markets. Ritter and more recently Brailsford et al. (2000) show results for different countries. They argue that overoptimistic investors and analysts' optimism signal riskier companies to take advantage of the "window of opportunity" to conduct an IPO (see also the prediction in Ljungqvist, Nanda, and Singh (2003) that average issuer quality decreases). This is consistent with the findings in Loughran, Ritter, and Rydqvist (1994) that issuers "time" their IPOs to coincide with periods of excessive optimism and in Lee, Shleifer, and Thaler (1991) that more firms go public when investor sentiment is high.

Helwege and Liang (2002) present evidence that technological innovations are not the primary determinant of hot markets, but they reflect greater investor optimism (for related evidence, see Lerner (1994), Loughran and Ritter (1995)). A related topic of investor sentiment lies in the positive feedback trading explanation where investors assume positive correlations in initial IPO returns, i.e., initial returns are likely to be bid up if the price of other recent issues has risen (for example, see Rajan and Servaes (1995)). Lowry and Schwert (2002) find empirically that the autocorrelation of monthly average first-day returns is even higher if 1998 to 2001 is included in the sample.

Another line in the IPO literature deals with the role of the (lead) underwriter and her influence on the aftermarket price, not only by pre-IPO decisions (offer price setting, allocation of shares), but also through actively participating in the secondary market. Underwriters are able to control for the amount of shares allocated in the market. Nowadays, the Green Shoe option (greenshoe, hereafter), so called after the first IPO that used it, is a standard instrument in allocating shares if there is strong demand. This overallotment option which amounts up to 15 percent of the shares offered enables the underwriter to buy back and retire the shares, as if they had never been offered, if the price weakens in the aftermarket (for example, see Ellis, Michaely, and O'Hara (2000)). Aggarwal (2000) presents empirical evidence that underwriters taking a (naked) short position prior to the IPO offering, especially in offerings where weak demand is anticipated, and provide price support by stimulating de- 
mand, the so called aftermarket short covering. She argues that price support can be seen as a complement to underpricing because underwriters try to prevent that potential buyers renege on their orders and cause a negative cascade if the aftermarket price is below the offer price.

A further interesting stream of IPO research focuses on the effect of underwriter's prestige or reputation (for an overview, see Logue et al. (2002)). While earlier studies find that more prestigious underwriters have left less money on the table, at least in the 1980s (see Beatty and Ritter (1986), Carter and Manaster (1990), and Carter, Dark, and Singh (1998)), other studies present evidence that this relation reversed in the 1990s (Beatty and Welch (1996)). Benveniste et al. (2003) and Loughran and Ritter (2003) recently report evidence for a positive relation between underpricing and underwriter prestige during the 1999/2000 hot market.

\subsection{Hypotheses and Explanatory Variables}

Based on the theoretical considerations and the insights of the literature reviewed above, we derive a set of explanatory variables which allow us to distinguish the importance of investor sentiment relative to that of ex-ante uncertainty in a joint analysis.

Considering the dynamics of the IPO market cycle and increasing investor sentiment we expect that more companies have an incentive to go public and to take advantage of the "window of opportunity" (see the discussion above and the related results in Baker and Wurgler (2000) who suggest timing ability of IPO issuers). In order to account for the issuing activity we use the volume of IPOs and calculate the total number of new issues during the last 30 days prior to an IPO. Due to the fact that volume is supposed to increase after periods of high underpricing the sign clearly depends on the state of the IPO cycle (hot or cold). Hence, a negative sign is expected as issuing activity tends to decrease when underpricing is highest (see the discussion above and the more recent results in Lowry (2003)).

More generally, we suggest that underpricing of IPOs can be attributed to rising stock markets. Aggarwal and Kunz (1994) and McGuiness (1992) were among the first who claimed this proposition. Loughran and Ritter (2002) show that initial returns are predictable based on market returns. They document the large effect that one percent increase in the market return during three weeks prior to the IPO date results in an initial return which is 1.3 percent higher. Giudici and Roosenboom (2002) present similar results for the 'new' European stock markets and suggest that the 'Internet euphoria' has an impact on underpricing. To capture this effect, we calculate a holding period return based on a suitable stock market index; the 'Nemax All Share' which represents all listings on the German new market ('Neuer Markt') for 30 days prior to an IPO.

Additionally, Ljungqvist (1997) argues that underpricing could be influenced by general macroeconomics conditions and their observation by investors (business climate) which forces the demand- 
or market-related underpricing, too. In order to incorporate this effect, the business climate index of current and future business expectations for Germany is used in our study.

Due to the role of underwriters in aftermarket trading and their use of the overallotment option for price support we newly introduce a dummy variable of greenhoe option usage by the underwriter. The indicator takes the value one if the maximum greenshoe has been allocated and zero otherwise. As outlined above, a positive sign is expected, especially in hot markets.

Considering ex-ante uncertainty which is mainly determined by asymmetric information problems, Ritter (1984) suggests that there would be a high degree of uncertainty about the fundamentals of a new issue, especially if the operating history of a firm is short. Consistent with his analysis, we use the age of a company as a proxy for such uncertainty perception of investors. We expect that the lower the age the higher the underpricing is.

Since Beatty and Ritter (1986) have introduced the idea that smaller IPOs yield a higher initial return because the offerings are more risky, market capitalization has been used as a measure for ex-ante uncertainty. Beyond this, Ljungqvist and Wilhelm (2003) document increases in mean and median issue size among U.S. IPOs as the market became hotter during the late 1990s. Contrary to the traditional asymmetric information hypothesis, we argue that in a more demand-led or investor-related market that higher IPO size subsequently leads to a greater coverage in the public and the media and, therefore, investors overpay for IPOs that are in the news. The latter is consistent with the findings in Dorn (2003) for the German Market. Because our market capitalization variable is defined inversely, we expect a negative correlation, in contrast to the ex-ante uncertainty argument

The traditional view of ex-ante uncertainty says that divergence in opinion between investors may lead to an increase in underpricing. Aggarwal and Conroy (2000) argue that delaying the first trade may enable the underwriter to better gauge market demand and could thus be an indicator of greater initial divergence in opinion to be followed by a higher underpricing (see also Loughran, Ritter, and Rydqvist (1994)). Contrary to this, in hot markets like in the 1998/1999 period where demand is very strong, underwriters reduce the subscription period. Following a demand and sentiment driven view we expect a negative relation between the length of the subscription period and underpricing, especially in hot markets where the sentiment effect dominates the uncertainty perception.

In a similar way, the bookbuilding range prior to the setting of the offer price signals ex-ante uncertainty in the more traditional view: the larger the range the higher the underpricing. As argued above, from an investor sentiment point of view a smaller range signals strong demand and therefore higher initial returns in the secondary market.

Consistent with the more recent studies cited above on the relation between underwriter's reputation and underpricing, we expect a positive relationship, especially in hot markets (see Loughran and Ritter (2003)). We use a dummy variable based on a ranking of all underwriters which is calculated 
using the total number of accompanied issues. The lead underwriters are grouped into three quantiles. The variable values one if the underwriter belongs to the highest rank and zero otherwise.

A summary of the proposed explanatory variables and the expected sign according to our investor sentment and demant hypothesis as well as ex-ante uncertainty can be found in Table I.

Please insert Table I around here

\section{Dataset}

\subsection{Essential Features of the German Market}

German secondary equity markets are fragmented both vertically and horizontally. In the horizontal dimension, stock trading is segmented into in eight regional exchanges and one electronic trading system XETRA which is operated by the Deutsche Börse AG. While the most liquid stocks are cross listed on all markets, the Frankfurt Stock Exchange is by far the largest competitor which is run by the Deutsche Börse AG, too. The others are in Berlin, Bremen, Düsseldorf, Hamburg, Hannover, München, and Stuttgart; some of them have specialized in a niche strategy like the warrant market EUWAX at Stuttgart. In our analysis, we focus on the Frankfurt markets managed by the Deutsche Börse AG because they cover more than 90 percent of the German equity market.

Until the $5^{\text {th }}$ of June 2003, the vertical fragments mainly consisted of three regulated market segments and two additional segments under private law (for an overview and more details see http://deutsche-boerse.com/dbag/). The 'Amtlicher Handel' created as a regulated segment for most of the liquid stocks was complemented by the 'Geregelter Markt' in the mid-eighties as a special segment for small- and mid-caps. The 'Freiverkehr' is a nearly unregulated inter-broker trading segment. The 'Neuer Markt' was founded in 1997 to support German growth stocks. Later on, an additional segment, the 'SMAX', was created for small caps from the old economy where the listing requirements were lower than in the 'Neuer Markt', but higher than in the traditional 'Geregelter Markt' (for an overview of the European new market wave in the 1990s, see for example Bottazzi and Da Rin (2002) and Ritter (2003)).

As a consequence of the bursting bubble in 2000/2001 and the following consolidation both the regulators and the Deutsche Börse AG made a clean sweep. Facilitated by changes in the Stock Exchange Act ('Börsengesetz') and the Stock Exchange Admission Regulation ('Börsenzulassungs- 
Verordnung') German exchanges now have more discretion in shaping their segments. While the two segments 'Amtlicher Handel' and 'Geregelter Markt' as defined by law exist in all German exchanges, the Deutsche Börse AG has created two new segments, additionally, the 'General Standard' and the 'Prime Standard'. The former one defines the basic requirements and the latter is designed for issuers aiming at international standards. Theoretically there would be four market segments, but in fact there are only two because the differences between the 'Amtlicher Handel' and the 'Geregelter Markt' within either the general standard and the prime standard are minimal.

\subsection{Description of the IPO Sample}

The dataset used in this paper covers the period 1997-2001 and contains all initial listings on the Frankfurt Stock Exchange. Companies being traded nationally or internationally before going public on the Frankfurt Stock Exchange have been excluded. Therefore, our 'sample universe' consists of 424 firms. Data for some explanatory variables, which are used for the cross sectional analysis, like book-building range, subscription period or foundation year are not available for 14 IPOs. Therefore, the 'regression sample' covers 410 firms.

Initial Public Offerings are taken from the Frankfurt Stock Exchange web pages and Factbooks, and always double checked with the IPO prospectus, company's homepage or investor relations department, the IPO database of the 'Börsenzeitung', and the IPO database of OnVista, in order to explore missing firms and entities which have been publicly traded before nationally or internationally. ${ }^{5}$ The company's foundation year is taken from the IPO prospectus, the company's web pages or the investor relations department. The Information about the bookbuilding period and price range are collected from the IPO prospectus, the Frankfurt Stock Exchange web pages or the IPO databases of 'Börsenzeitung' and OnVista. The use of the greenshoe is taken from the 'Börsenzeitung' web pages, ad-hoc information services or the company's investor relations department. The information about the number of issued stocks is taken from the IPO prospectus, and Deutsche Bank IPO database. The information about the underwriter is taken from the Frankfurt Stock Exchange web pages and the IPO database of the 'Börsenzeitung'. The free float information is taken from the Frankfurt Stock Exchange web pages, the IPO prospectus and the Deutsche Bank IPO database. The secondary market prices are obtained from the KKMDB database at the University of Karlsruhe. ${ }^{6}$ Daily closing prices of the different stock market indices are taken from Datastream. Industry classification (C-DAX classification) is taken from the Frankfurt Stock Exchange web pages or from OnVista, 'Börsenzeitung', and Comdirect web pages. The business climate index is from the monthly OECD statistics.

\footnotetext{
${ }^{5}$ WindWelt for example was missing on the web pages and Factbooks of the Deutsche Börse AG.

${ }^{6}$ We thank Hermann Göppl for providing the data.
} 


\section{$4 \quad$ Empirical Analysis}

\subsection{Firm Characteristics}

To provide general information, Table II shows some details based on descriptive statistics for each year and the whole sample period. We also split the year 2000 into two subperiods because in March 2000 the bubble started to burst. We have chosen January to July for the first sub period as after July the number of IPOs decreased sharply and the stock market experienced another decline but this time even more severe. To use March instead of July, the peak of the stock market indices for separating the sample would not take the well documented conservatism phenomenon into account, which states that investors need some time to finally realize a sentiment change.

Please insert Table II around here

The average issue volume amounts to 107.97 Million $€$ over the sample period but is highly skewed due to some big offerings as the median is only 36.79 Million $€$. The smallest issue was OAR Consulting in 1998 with 4.3 Million $€$ and the largest IPOs were Deutsche Post in Nov. 2000 with 5,842 Million $€$, Infineon in March 2000 with 5,379 Million $€$, and T-Online in April 2000 with 2,538 Millon $€$. Hence, the biggest IPO is 1,358 times bigger than the smallest. The issue volume fluctuates quite substantially peaking in 2000 due to big offerings in the second subperiod. These figures are much higher than earlier years. For example, Ljungqvist (1997) reports ${ }^{7}$ for 1970-1993 a mean of 134.7 Million DM (68.87 Million $€$ ) and median of 57.2 Million DM (29.25 Mill. €).

Market capitalization which gives a better feeling of the different company sizes, as it also covers shares retained by the issuer, demonstrates that the biggest firms were brought to the public in 2000 and 2001. The largest firm measured in market capitalization at the IPO date was Infineon with 21,584 Million $€$. This shows that either big firms do not care much about the stock market sentiment or are simply too slow to react fast enough to a short living IPO boom. Especially, the clear decrease in median but slow decrease in the mean supports this idea. Jindra (2000) finds in his analysis for the U.S. market that a small number of firms issue seasoned equities while they are undervalued. Examining this group, he explores the idea that this cluster consists mainly of large and old companies issuing little equity. Similarly, in our sample the age of the company increases in the second sub period of

\footnotetext{
${ }^{7}$ As we exclude the unregulated 'Freiverkehr' due to unreliable data, we use the issue volume without the 'Ungeregelter Freiverkehr' reported by Ljungqvist (1997), to compare our figures.
} 
2000 and in 2001, and the issue volume tend to decrease because the median of the issue volume drops rather sharply.

The average age of 17.59 years compared to 52 years reported for the earlier years by Ljungqvist (1997) together with the low sample minimum of 0.98 and median of 10.32 suggests that the majority of firms which went public during the sample period on the Frankfurt Stock Exchange are relatively recently founded firms. This result is in line with an average age of U.S. IPOs of 13.3 (median 7 years) for the years 1996-2000 reported by Ljungqvist and Wilhelm (2003) and also with Loughran and Ritter (2003).

The initial returns are again heavily right skewed. The average first-day return amounts to $44.47 \%$ and peaks at a stunning $444.44 \%$ for Biodata Information Technology in February 2000, the peak of the IPO boom. The annual average return fluctuates quite substantially with $64.10 \%$ in 1998 and 5.32 $\%$ in 2001 . Therefore, it is quite obvious that the different degree of underpricing reported all over the world depends mainly on the reported time period. Kiss and Stehle (2002) report an initial return of 49.04\% for the 'Neuer Markt' over the period 1997 to 2001. Erhardt and Stehle (1999) report for 1960-1995 only moderate underpricing of $15.79 \%$ with a sample maximum of $200 \%$. During our sample period 15 firms have an excess return of more than $200 \%$ and 65 new issues gain more than $100 \%$. The first-day closing price was below the offer price for 65 new issues representing $15.85 \%$ of the sample. This result is above the $8.7 \%$ reported by Wasserfallen and Wittleder (1994) for the 19611987 period and exceeds slightly the 15\% stated by Hansson and Ljungqvist (1992) for the years 1978-1991.

To get a first idea about the investor sentiment prevailing during the sample period one could look at the price revision which is measured as the percentage change of the expected offer price during the bookbuilding range. This figure is assumed to reflect the information acquired from investors during the information process (see Hanley et al. (1993) and Ljungqvist and Wilhelm (2003)). The average is a 3.92 percent increase with a median of $6.98 \%$. It is rather interesting that during 1998 until early 2000 which can be considered as the IPO boom, the price revision is highest and that the acquired information leads in 2001 and late 2000 to a reduction of the expected offer price. Price revision are obviously influenced by the width of the bookbuilding range as this sets the upper and lower limit. Again, it can be seen from Table I that during periods of high underpricing and therefore high price revision, the width of the bookbuilding range is rather low. Ljungqvist and Wilhelm (2003) find an average price revision of $5.8 \%$ which peaks at $18.7 \%$ in 1999 , this relative high figure is due to the fact that in the US the initial price range can be adjusted upwards during the offer period, leading to a potentially higher price revision. Thus, simply comparing U.S. and German figures lead to a biased conclusion. Bookbuilding days, reflecting the subscription period, are lowest during periods of high first-day returns. This time series shows a negative trend at the beginning of the sample and is increasing as the return of the stock market index is decreasing which indicates a cool down of the in- 
vestor sentiment after the bubble. The idea that investor sentiment drives IPOs first-day returns is supported by the buy and hold return of the Nemax All Share Index which represents all stocks traded on the 'Neuer Markt', as this return is highest when underpricing peaks.

The sample period was dominated by the IPO boom and high public attention towards the "New Economy'. In order to have a closer look at the different industry groups, Table III shows some descriptive statistics whilst Table IV presents results of additional dummy regressions

Please insert Table III around here

From Table III it is apparent that 'software' represents, with 147 firms, the majority of the Initial Public Offerings during the sample period and that 'software' combined with 'technology', the two biggest industry groups, represent $55.37 \%$ of all IPOs. We group 'media' (49 firms), 'pharma \& health' (35 firms), 'software' (147 firms), 'technology' (80 firms), and 'telecommunications' (19 firms), which represent $80.49 \%$ of the total sample, together to form the 'New Economy'. It's rather interesting that IPOs out of this group yield the highest underpricing but also the highest negative firstday return.

Brainpower N.V., belonging to the 'software' group, went public in September 2000 and yields a initial return of $-30.00 \%$ and LS Telecom AG, belonging to the 'telecommunications' groups yielding a first-day return of $-28.40 \%$. The highest initial returns were reported for Biodata Information Technology AG, 'technology' group (IPO in February 2000) and Drillisch AG, 'telecommunications' group, (IPO in April 1998) yielding 444.44\% and 403.50\%, respectively. It's also interesting to note that the 'software' group includes the biggest high flyer but also many firms with zero or negative first-day returns. Out of the 'New Economy' 188 IPOs yield a zero or negative first-day return, representing $45.85 \%$ of this sample. These results support the observation of Schultz (2003) who finds that firms which are relatively unprofitable, use periods of good investor sentiment and high first-day return, the so called 'windows of opportunity' (Loughran and Ritter (1995)) to go public.

Ritter (1984), Helwege and Liang (2002), and Rajan and Servaes (1997) show that the 'hot issue' market is due to an increased issue activity of some industries. Inspecting Table II it becomes obvious that the German hot-issue market is mainly represented by the software and technology group, representing $55.37 \%$ of the total sample. The 'New Economy' represents 330 firms and therefore $80.49 \%$ of the regression sample

Again, these results highlight the fact that the reported results clearly depend on the underlying period. As we start our analysis with the foundation of the 'Neuer Markt' and therefore, prior to the IPO- 
Boom, and also includes the year 2001, which is clearly surrounded by a negative investor sentiment, we control for different market conditions in our below empirical analysis.

\subsection{Underpricing of Industry Groups and Market Segmentation}

Before we start our econometric analysis we have a closer look at the different industry groups as well as at the three stock market segments. Loughran and Ritter (2003) report that internet and technology stocks show higher mean first-day returns and Ljungqvist and Wilhelm (2003) find a significant and positive influence of internet and high-tech companies, which he labeled 'New Economy', on price revision and the degree of underpricing. Lowry and Schwert (2002) find that the 'high tech' industry is surrounded by higher underpricing. Thus, we run different dummy regressions using the industry classifications and the vertical stock market segmentation as regressors and present the results in Table IV.

Please insert Table IV around here

Regressing the initial return on the different industry dummies, where initial return is defined as $\ln \left(\mathrm{P}_{\mathrm{t}} / \mathrm{P}_{\text {offer }}\right), \mathrm{P}_{\mathrm{t}}$ represents the first-day closing price and $\mathrm{P}_{\text {offer }}$ the offering price, respectively, shows that in (1) none of the industry classifications which can be considered as the 'New Economy' have a significant effect.

There is quite a controversy whether first-day returns should be adjusted for market movement or not. Erhardt and Stehle (1999) point out that it does not make a big difference if the initial return is adjusted for the market movement or not. Loughran and Ritter (2002) show that the average market return was $0.05 \%$ per day in the U.S. market. In our sample the average return of the Nemax All Share index, calculated as the arithmetic mean, was only $0.098 \%$ per day. Given this result both methods seem to be adequate, if the correct benchmark has been chosen. We also analyze the potential impact of the price support, adjusting the raw returns for market movement would introduce bias into our analysis. Thus, we use raw returns which have been used by nearly all recent studies.

Surprisingly, none of the industry dummies yield a significant result. Only 'transportation \& logistics' and 'finance' are close to the $10 \%$ level. Using only industries belonging to the 'New Economy' as explanatory variables in Regression (2) shows on the one hand that 'media', 'software' and 'technology' yield a significant and positive regressor and on the other hand that 'pharma', which mainly comprises of biotechnology companies, and the 'telecommunication' sector does not yield a significant result. Due to these results one could maintain the argument that the C-DAX classification, used 
by the Frankfurt Stock Exchange, was not very precise at this time period. Taking this possibility into account we group the 'New Economy' to one single dummy which yields a significant result and a highly significant F-statistic.

Examining the impact of the different market segments in regression (3) shows that a listing on the 'Neuer Markt' boosts the underpricing by $14.2 \%$. This result supports the hypothesis outlined above, that the initial return is driven by investor sentiment and strong demand for the new issue, as this stock market segment had been closely watched by investors and the media which led to many oversubscribed $^{8}$ issues in 1999 and 2000. This argument is supported theoretical by Merton (1987) who shows that investors are only able to cover a limited amount of stocks.

\subsection{Hot-Issue Markets: The Dynamics of the IPO Market Cycle}

Ritter (1984) and Hansen et al. (1987) were the first to demonstrate that the issuing activity is time dependent and that hot-issue periods are characterized by large first-day returns and increasing number of new issues. They are usually followed by periods of low underpricing and relatively few IPOs. This results have also been reported by Loughran and Ritter (2002) and Lowry (2003), recently. Wasserfallen and Wittleder (1994) show for Germany over the period 1961-1987 that hot and cold issue periods can be distinguished by analyzing the trading volume and the monthly degree of first-day returns.

Please insert Figure I around here

Analyzing Figure I which graphs the quarterly IPO volume no clear lead-lag relationship between the two series can be distinguished, as proposed by Lowry and Schwert (2002) in the U.S.

In order to shed more light on the hot-issue market and the potential seasonality in the time series different regression are used and stated below.

\footnotetext{
${ }^{8}$ Examples for oversubscribed issues: Deutsche Börse AG (23-times), Dr. Hönle AG (2-times), Infineon (33times), OnVista AG (80-times), Pgam Advanced Technologies AG (13-Times), PopNet Internet AG (70times), Sunways AG (33-times), T-online (4,4-times), and Winter AG (14-times).
} 


\subsubsection{Seasonality of the Initial Return and Number of IPOs}

While examining the graph it is apparent that the underpricing per quarter exhibits a clearly decreasing seasonal cycle and that it nearly always peaks at the first quarter. The issue activity shows the clustering pattern predicted by Schultz (2003) for the U.S.

Please insert Table V around here

In regression (7), (9), and (11) the dependent variable, $\mathrm{y}_{\mathrm{t}}$, is represented by IR $1_{\mathrm{t}}$ and in regression (8), (10), and (12) by IPO-Volume. Dummy1, dummy2, and dummy3 are coded one for the first, second and third quarter of the year, respectively, and zero otherwise. The trend-dummy is coded one for the first quarter, two for the second, and increases up to 19 for the last quarter in the sample period. The results are stated in Table V.

The lag length of the augmented Dickey-Fuller test has been chosen by using the general to simple approach of $\mathrm{Ng}$ and Perron (1995), or by applying the Schwartz and Akaike info criterion. This shows for the average initial return on a quarterly basis a t-statistic of 0.071 and for the quarterly IPO volume -2.287 (10\% critical value: -2.690$)$. Given the results we cannot reject the null hypothesis of both series having a unit-root. Admittedly, the evidence for IPO volume is not very strong, but as the impact of potential nonstationarity, which has not been treated appropriately, is rather devastating for the OLS regression, we use the first difference of IPO volume and IR1 as dependent variables.

Neither initial return nor issue activity show a clear trend, as none of these trend dummies is significant and no F-statistic yields a significant value. From regression (3) it can be seen, that underpricing is highest during the first quarter of the year. This suggests the existence of some form of the January effect. Lowry (2003) finds examining IPOs between 1960 and 1996 that the issue activity is lower during the first quarter of the year which she assumed is due to the 'quiet period' between Christmas and New Year. We cannot confirm this pattern but find that issue activity is highest during the second quarter of the year as the dummy 2 is significant at the $5 \%$ level. A first idea about the relationship between IPO volume and underpricing can be obtained by combining regression (11) and (12) as dummy 1 has a p-value of 0.015 and dummy 2 a p-value of 0.017 , respectively. Thus, the high average first-day return of the first quarter is followed by an increase in the issue activity.

Rather surprising is the relatively high adjusted $\mathrm{R}^{2}$ of 0.525 and 0.511 for IR1 and volume in Regression (5) and (6), respectively. This suggests that these variables (IR1 and volume) can be described quite well during the years 1997 to 2001 by variables which cover the seasonality effect. Therefore, we include the issue activity which should proxy the seasonality quite well in our crosssection analysis of the first-day return. 
The above patterns suggest high first-order autocorrelation coefficients. Lowry (2003) reports that the first-order autocorrelation of quarterly IPO volume between 1960 and 1996 equals 0.87 and that some evidence for nonstationarity can be found. Brailsford et al. (2000) report 0.66 and 0.89 for the first order autocorrelations coefficient of monthly average initial returns and IPO volume. In our sample the first-order autocorrelation coefficient of quarterly average initial returns and volume is 0.251 (t-statistic: 0.993 ) and 0.803 (t-statistic: 5.398), respectively. The first-order autocorrelation coefficient of monthly data yields 0.567 (t-statistic: 5.205 ) for IR1 and 0.612 (t-statistic: 5.840 ) for volume. These lower levels of persistence may reflect the more turbulent period that we analyze and offer a greater challenge for our more structural cross-section modeling.

\subsubsection{Predictability of the Issue Activity (IPO volume)}

The lower levels of persistence we find raise the question of the relationship between IPO volume and initial return. From inspecting the graphs in Figure I no exact period can be distinguished which shows the anticipated relationship of high average initial returns being followed by high issue activity. But it can be seen from Table I that the high underpricing in 1998 is followed by a clear increase in issue activity during the years 1999 and 2001. Additionally, regressions (11) and (12) show also some evidence of a lead-lag relationship.

Ibbotson and Jaffe (1975) run a time series regression of IPO volume on lagged values of monthly average underpricing in order to test the influence of past initial return on the issue activity. As their regressors are insignificant they conclude that the timing of new issues is not related to the degree of underpricing of the previous month. Ritter (1984) re-examined this matter analyzing the graphs and found, that the issue activity is influenced by lagged initial returns. Recently, Lowry and Schwert (2002) find that IPO volume is influenced by past average monthly initial return.

We re-examine Ibbotson and Jaffe (1975) regression for our data. Due to doubts about the exogeneity of the explanatory variables we use different restricted and unrestricted vector autoregressions in order to have a closer look at issue activity as well as monthly average initial returns. Lowry and Schwert (2002) note that VAR models allow for substantial serial correlation. The lag length for regression (16) and (17) has been chosen using the Akaike information criteria.

Please insert Table VI around here

For regression (13) the variables have been tested for nonstationarity using the augmented DickeyFuller test, where again the lag length has been chosen using the general to simple approach. We can reject the null hypothesis of IR1 and volume having a unit root at the $1 \%$ level. 
Supporting the theory that high initial return is followed by an increase in issue activity we find that variable IR1(t-2) and IR1(t-3) have a positive coefficient and p-values of 10.711 and 20.103, respectively. Contrary to Ibbotson and Jaffe (1975), we can conclude while examining regression (13) that an increase in underpricing in period t-3 of one percent point will lead to four additional issues in period t.

A more profound implication can be drawn from the following restricted and unrestricted VAR models, where we first analyze the dynamic behavior of the issue activity and subsequently, monthly average initial returns.

From the Granger causality statistics for the unrestricted VAR Regression (14) it can bee seen, as IR1 has a $\chi^{2}$ (Wald) statistic of 11.82385 (p-value: 0.0187 ), that lagged values of monthly average initial returns help to predict IPO activity. To have a closer look at the dynamics we plot simple impulse response functions in Figure II. The first row shows the effect of an unexpected Cholesky one standard deviation increase in volume and IR1 on the issue activity. It can be seen from the left hand side figure that volume peaks in $\mathrm{t}+5$ and $\mathrm{t}+9$ after a shock in volume. From the right hand side figure it can be ascertained that a one standard deviation increase in IR1 cause a sharp increase in the issue activity after a few month, which persists over a longer period. Also plotted are plus/minus two standard error bands, which yields an approximate 95 percent confidence interval for each of the impulse responses.

Please insert Figure II around here

Contrary, while analyzing the dynamic behavior of monthly average initial return, the Granger causality test for the unrestricted VAR regression (15) yields an insignificant result for the IPO activity. Given these results we run a restricted VAR where we solely use lagged values of IR1 as explanatory variables. The results are stated as regressions (16) and the Granger F statistics yield a significant effect at the one percent level. The second row of Figure II shows a shock of IR1 and the dynamic impact on initial returns. It can be seen that the innovation in t slowly dies away over time and shows a convex function.

\subsection{Underwriter Activity in the Secondary Market: Price Support}

In modelling the initial returns, the possible existence of aftermarket price support has an important impact on the estimation method as the price support of underwriters could lead to a shift of negative observations, which would lead to a truncation of the left hand side of the distribution. Using Ordinary 
Least Squares (OLS) in the presence of a censored dependent variable could lead to biased and inconsistent parameter estimates as the error term would not have a zero mean.

In order to offer concrete evidence for or against the existence of underwriter price support it would be necessary to acquire information about which offers have been stabilized. Unfortunately, this information is, as for many other stock markets, not available for Germany. Therefore, following Ruud (1993) inference is drawn from the distribution of IPO returns ${ }^{9}$. If IPOs were underpriced deliberately this should lead to a bell-shaped curve with the peak of the distribution centered on a positive mean. Figure III shows that initial returns peak rather steeply around zero, and that the negative tail of the distribution is significantly curtailed, as Ruud also found (1993). Relatively few IPOs fall much below their offer price.

It is apparent that the log-returns are not symmetrically distributed and that a relative high number of IPOs have first-day returns close to zero, which may be due to this censoring effect. The skewness and kurtosis are 1.184810 and 3.855068, respectively. These findings have been confirmed for other stock markets as well. For example, Keloharju (1993) reports that over the period 1984 to 1989 that initial returns in Finland are skewed to the right and have excess kurtosis. Kaserer and Kempf (1995) also report high skewness and excess kurtosis for Germany for the period 1983 to 1992.

Please insert Figure III around here

Ruud (1993) finds in her analysis by covering a sample of 463 IPOs over the years 1992 and 1993, that $25 \%$ of the sample has a first-day return of zero and that the one-day return is heavily skewed to the right. However, this skewness gradually decreases in the first four weeks of trading. This effect has been interpreted as steady removal of underwriter's price support. The distribution of IR1 is shown in Figure III and the descriptive statistics of the distributions is summarized in Table VII.

Please insert Table VII around here

\footnotetext{
${ }^{9}$ An analysis of underwriter price support using Ruud's (1993) analysis has been conducted for the German market by Kaserer and Kempf (1995) who found no support for stabilizing bids by the underwriter. Mihurko (2000) analyzing the German 'Neuer Markt' over the period 1997 to 2000 found evidence for stabilizing activities by the underwriters.
} 
As noted above, in order to be consistent with the price support hypothesis proposed by Ruud (1993), one should expect a steady decline of skewness in the aftermarket. Table VII gives a summarized overview about the distribution of the IPO log-returns over the first 30 trading days.

Skewness, which is based on the third moment of the distribution, declines with the number of trading days. The sharp decline during the first 15 trading days suggests that underwriter price support decreases over time. The mean is relatively constant over the first 30 trading days, whereas the minimum drops already in the first week and again sharply in week three and five suggesting the removal of underwriter price support in the secondary market. Therefore, it seems to be reasonable to argue that underwriters do not support the issue constantly but time their actions.

Fama (1976) finds that monthly stock returns measured in logs are, in contrast to daily log-returns, positively skewed and are close to normal in terms of kurtosis. The above stated results are nearly consistent with Fama's findings, whereas the daily log returns are neither consistent with either Fama's (1976) nor Peiró's (1999) results.

In order to shed more light on the existence of underwriter price support we examine, following the dynamic analysis of Ruud (1993), IPOs with zero or negative first-day returns, as these issues are most likely supported in the secondary market.

Please insert Figure IV around here

Ruud (1993) found that only $8 \%$ of IPOs with zero first-day returns exhibit one-week subsequent returns greater than $5 \%$ and additionally that $69 \%$ of IPOs with zero first-day return exhibit zero or negative one-week returns. Figure IV shows that IPOs with an initial zero or negative return trade on average during the first 30 days below the offer price. This, highlights the possible existence of a negative cascade effect as in Welch (1992). Surprisingly, there is clear increase in the returns of these stocks at day 28 and 29 , which could be due to the expiration of the overallotment option. We analyze the use of the greenshoe to shed more light on the price support phenomenon given this pattern of returns

Please insert Figure V around here

Aggarwal (2000) points out that an underwriter has 30 days to exercise the option, on average. As price support is costly, the increase in returns that we find on day 28 and 29 could be interpreted as evidence that underwriters wait till the near expiration of the greenshoe option and create a demand driven increase in the stock price. 
From Figure $\mathrm{V}$ we can see that the pattern of the holding return over the first 30 trading days, if no greenshoe is used, supports the finding of Aggarwal (2000), namely that greenshoe is the main source of price support in the secondary market. Comparison of the two sets of returns for those who used the greenshoe and those who did not is clearcut. The pattern of initial returns when the overallotment option has been used, leads to the possibility that an underwriter wants to stop issues from dropping below the offer price, and that they use the residual of the greenshoe prior to the expiration of the option.

\section{Cross-Section Regression}

In this section we examine the relationships between underpricing, ex-ante uncertainty, investor sentiment as well as other explanatory variables and the possible impact of price support. Regressions (18) and (19) are presented to assess if ex-ante uncertainty or investor sentiment is the main force driving initial returns during our sample period. Regressions (20) and (21) measure the influence of the hot-issue markets. Regressions (22) and (23) combine all variables to give an overall comparison of the strength of the two approaches. The range of regressions has been chosen to give an impression of the robustness of the models concerned. Finally, regressions (24) and (25) are presented to assess the impact of sd, i.e., the standard deviation of aftermarket closing prices divided by the issue price, on the models concerned.

Please insert Table VIII around here

Given our theoretical explanations and the earlier results it is not surprising that only age has the sign which would have been expected according to Rock's (1986) theory (see regression (22)). As the t-statistics for most of the variables intended to measure both ex-ante uncertainty and investor sentiment, across regression (18) to (23) are close or above 2, the wrong sign can hardly be due to possible multicolliniarity (Kennedy (1996)).

The negative signs of the new variables $b b d$ (length of subscription period) and $b b w$ (width of bookbuilding range) indicate that the 'speculative' effect dominates. Calculating the exact percentage impact of the above variables in the OLS regression (22) shows that IR1 increases by $10.19 \%$ and 9.70 $\%$ if $b b d$ and $b b w$ fall by one percent, respectively. If we control for the possible truncation of returns at zero, the Tobit regression (23) shows that IR1 increases by $11.04 \%$ and $10.77 \%$ if $b b d$ and $b b w$ decline one percent. Age is significant at the one percent level and yields a negative coefficient, which suggest that the true market value for older companies can be better evaluated than for younger firms. Wasserfallen and Wittleder (1994) report a negative and insignificant relationship between under- 
pricing and the age of the company for the years 1961-1987. Ljungqvist and Wilhelm (2003) find a significant and negative relationship for 1996 to 2000 supporting our results.

Marketcap has a negative impact as would be expected given the argument that the initial return is mainly driven by the investor sentiment; bigger firms are associated with a higher first-day return. Even though, the results lack significance at conventional levels one could maintain the argument that speculative investors submit more purchase orders for these companies in hope that stocks of bigger firms perform better in the secondary market. Despite this, Ljungqvist (1997) reports a positive and significant relationship between underpricing and offer size. Wasserfallen and Wittleder (1994) use the level and not the inverse of the gross proceeds, but cannot find a significant relationship between underpricing and the size of the company.

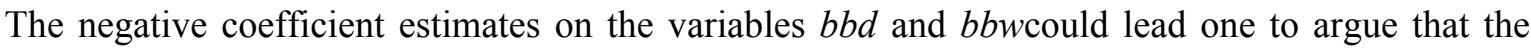
unusually high first-day return is driven mostly by speculative investors purchasing orders in the secondary market than by ex-ante uncertainty about the true market value of the IPO. Follwing this argument a smaller bookbuilding range and shorter subscription period represent more certainty for the underwriter about the true market value which, according to Kim and Ritter (1999), is strongly influenced by investor demand. This argument is supported by the fact that in our data the holding period return after the first 30 trading days is still $12.79 \%$. By contrast, Hansson and Ljungqvist (1992) report a negative return for the first weeks of trading during the years 1978-1991.

Loughran and Ritter (2002) show that 86\% of all IPOs in the U.S. over the period 1990 to 1998 had an average bookbuilding range of $2 \$$ (measured as the difference between upper and lower bound), compared to $4.08 €$ (equivalent ${ }^{10}$ to $4.20 \$$ ). This high figure, compared to the U.S., indicates the difference in the bookbuilding process, as in the U.S. the initial price range can be adjusted upwards or downward, which is not possible in Germany. This raises the question about how underwriters set the subscription period and boobkuilding range for individual IPOs. In our data the average boobkbuilding period and the bookbuilding range divided by the midpoint is 6.3 days and $18.95 \%$ for firms with zero or negative first-day return and 5.7 days and $17.02 \%$ for firms with positive first-day returns, respectively. The average announced greenshoe represents $12.01 \%$ of the issue volume for non successful IPOs and $11.16 \%$ for underpriced issues. All this could be interpreted as hinting that if the underwriter anticipates poor prospects for the IPO, they will increase both the period during which investors can subscribe and the range of the possible issue prices. It should be noted in this context that rather surprisingly the Nemax All Share index rose on average 19.75\% during the last 90 trading prior to the IPO for successful issues and $-9.11 \%$ for IPOs with zero or negative first-day return.

\footnotetext{
${ }^{10}$ We used the exchange rate $1 €=0.97 \$$ (equally weighted average during our sample period ). At the current exchange Rate $1 €=1.25$ ( $1^{\text {st }}$ of March 2004) the difference between the upper and lower bound of the bookbuidling range would be $3.266 \$$.
} 
The negative and highly significant coefficient on volume provides evidence that the reported seasonality of the issue activity quite substantially influences the first-day return. Consequently, average underpricing decreases as the number of new issues increases. Therefore, this suggests that the market takes some time to respond to high first-day returns. Lowry (2003) suggests that during some periods investors are overly optimistic and are willing to pay more for firms than they are worth. The variable market, measured as the buy-and-hold return during the last 30 trading days prior to the IPO, and the dummy variable greenshoe, are positive and significant at the $1 \%$ levels. The result of these variables again supports the idea that underpricing is mainly driven by investor sentiment and strong demand for the IPO.

In contrast to Ljungqvist (1997), the business cycle variable $b c$ is insignificant at standard confidence levels which leads either to the conclusion that business climate has no effect on the initial return. Measurement error in the OECD variable during the IPO boom is an alternative explanation. Both underwriter dummies also lack statistical significance.

As outlined above, the possible existence of aftermarket price support could have an important impact on the consistency of the estimation method. Using OLS in the presence of a censored dependent variable could lead to biased and inconsistent parameter estimates. In order to account for this phenomenon we provide estimates using the Tobit method. The differences between the results for the two estimation methods in (18) to (23) are rather small, the coefficients change only slightly as does the level of significance. The variables in regression (21) which are supposed to measure the impact of the hot-issue market all become slightly more significant and the variables in regression (19) all become slightly less significant. One noticeable change is the sign of the variable underwriter 2 which is in regression (21) positive and, therefore, strengthening the idea that underwriter who accompanied many IPOs are able to grip the investor sentiment and demand best. Overall, the difference between the OLS and Tobin regressions suggest that the effect of the censored data is not as big as might be anticipated.

The adjusted $\mathrm{R}^{2}$ of regression (20) emphasizes the fact that variables influenced by the existence of the hot-issue market and therefore optimistic investors explain the variation in the initial return best. The adjusted $\mathrm{R}^{2}$ of $33.3 \%$ is well above the $21 \%$ reported by Wasserfallen and Wittleder (1994) and also exceeds the $31.2 \%$ given by Ljungqvist (1997).

Wasserfallen and Wittleder (1994) used a set of variables and reported that only standard deviation shows a significant effect. To round off our reassessment of the underpricing puzzle for the German market we incorporate this variable to document the stunning effect of this often used risk measure on our explanatory variables. The variable age becomes insignificant. The variables marketcap and underwriter 2 become significant at the $10 \%$ level and underwriter1 slightly misses this level in regression (24). The Tobit estimates show that this time underwriter1 becomes significant, whereas underwriter2 is insignificant. Sd itself is highly significant using both estimation methods. The adjusted $\mathrm{R}^{2}$ 
jumps to an amazing 50\% level. The RESET-test had to be rejected for one and two fitted values at the one percent level, but cannot be rejected for all other regressions. Therefore, incorporating sd changes the results quite substantial. This effect could be due to serious correlation between sd and other explanatory variables. Therefore, running a regression where sd is the dependent variable shows that age, bbd, greenshoe, and nemax are highly significant and that underwriter 1, underwriter 2 and marketcap are slightly insignificant. Ljungqvist (1997) noted that this variable might induce simultaneity bias due to failure of strict exogenity. This is due to the fact that price support effectively limits volatility by inducing a low bound. Additionally, it can be argued that standard deviation might be jointly endogenous due to the fact that underpricing may influences the price movements in the secondary market. Given the above outlined argument, we have to conclude that the standard deviation should not be used as an explanatory variable in the analysis of underpricing.

A crucial question has been raised by our analysis. Why does the issuers and/or underwriter not set the initial bookbuidling range higher in order to earn more money for the issuer? This question is even more important for Germany as the initial price range can not be adjusted upwards, as in the U.S. Loughran and Ritter (2002) report that during the 1990 to 1998 period the issue price was below the initial price range for $27.3 \%$ and above the initial price range for $24.3 \%$ of the IPOs. Allowing the adjustment of the initial price range would in our opinion mislead more unprofitable firms to go public during an IPO-Boom as they can maximize their revenue, thus resulting in an even more potential damage to the private investor.

There are different, but not mutually exclusive explanations for this question. First, a lower issue price makes it easier to find investors and, therefore, reducing marketing costs (see Baron (1982)). ${ }^{11}$ Second, investors who are eager for hot IPOs start trading with the underwriter and, therefore, pay fees for transaction and accounts in order to get hot-issue shares allocated. Third, following Tinic's (1988) legal liability hypothesis underwriters cannot raise the issue price any further as this could cause legal frictions in the future.

Loughran and Ritter (2002) show, using Prospect theory, that issuers care more about the change in their wealth rather than the level of wealth. Daniel (2002) states that during hot-issue periods the bargaining power of the underwriter is stronger than of the issuer, therefore resulting in a lower issue price. Due to the closed order book, this can be used by the underwriter to allocate the stocks to his favorite customers which results in a stronger business relationship. In support of this view, Ljungqvist and Wilhelm (2004) find that few firms change underwriter for their first Seasoned Equity Offering.

\footnotetext{
${ }^{11}$ See Daniel (2002) for an interesting description of the pricing process of Microsoft.
} 
Another proposed explanation for not setting the issue price too high is based on Welch's (1992) cascade theory. Daniel (2002) shows that an exaggerated offer price would cause high quality investors to drop out of the offer, thus, possibly starting a negative cascade. The fact that the potential firstday return to the investor was $44.47 \%$ during the sample period and peaks at $64.10 \%$ in 1998 suggests that the order of magnitude of underpricing is too large for this theory to be persuasive.

\section{Conclusion}

Previous studies often claim that underpricing is a deliberate activity either by the underwriter or the issuer. Stimulated by unusually high first-day returns during the Dot-com bubble and the view that underpricing is a combination of true discount and market reaction, we ask the question whether underpricing during the IPO boom is really driven by ex-ante uncertainty or by investor sentiment and demand. In order to shed more light on this important question we analyze a sample of 410 German IPOs which went public on the Frankfurt Stock Exchange over the period 1997 to 2001, using both OLS and censored data estimation. The concluding cross section analysis builds on an initial analysis of the cyclical behaviour of issue activity and underpricing, and, additionally, on the possible existence of underwriter price support in the German secondary market.

Analyzing the hot-issue market during our sample period we find that underpricing peaks during the first quarter of the year, thus, showing a form of January effect for the German IPO market. Analyzing the lead-lag relationship between issue activity and underpricing we find that the decision to go public is influenced by both past underpricing and volume. Additionally, we find that volume and initial return are serially correlated.

A second phenomenon influencing the degree of underpricing and any analysis of the cross-section of initial returns is the truncation of initial returns due to price support by the underwriter. Examining the distribution of first-day returns, and especially negative or zero first-day returns, we provide detailed evidence of supporting activity of the underwriter. In line with Aggarwal (2000) we find that the greenshoe seems to be the tool for price stabilizing activities.

Building upon these results we run different cross-section regressions. Interestingly, the variables $b b d$ (length of the subscription period) and $b b w$ (width of the bookbuilding range) have negative effects. This leads to the conclusion that underwriters as they are setting these periods and price ranges in advance, expect higher demand of possible investors and, therefore, less uncertainty about the true market value of the upcoming IPOs which are finally more heavily underpriced. We also show that older companies can be evaluated best leading to lower first-day returns. Variables measuring investor sentiment and demand, like the average issue volume, market movement and usage of the greenshoe show very significant results. We conclude that during periods characterized by the presence of highly 
optimistic investors, ex-ante uncertainty is not the dominating source for underpricing and that investor sentiment dominates the determination of the initial return.

\section{References}

Aggarwal, R., 2000. Stabilization activities by underwriters after initial public offerings. Journal of Finance 55. 1075-1103.

Aggarwal, R., Conroy, P., 2000. Price discovery in initial public offerings and the role of the lead underwriter. Journal of Finance 55. 2903-2922.

Aggarwal, R., Kunz, R. M., 1994. Why initial public offerings are underpriced: Evidence from Switzerland. Journal of Banking and Finance 18. 705-723.

Aggarwal, R., Leal, R., 1998. German banks and the new issues market. Working Paper. Georgetown University.

Allen, F., Faulhaber, G. R., 1989. Signalling by underpricing in the IPO market. Journal of Financial Economics 23. 303-323.

Amihud, Y., Hauser, S., Kirsh, A., 2003. Allocations, adverse selection, and cascades in IPOs: Evidence from Tel Aviv stock exchange. Journal of Financial Economics 68. 137-158.

Baker, M., Wurgler, J., 2002. Market timing and capital structue. Journal of Finance 57. 1-32.

Baron, D. P., 1982. A model of the demand for investment bank advising and distribution services for new issues. The Journal of Finance 37. 955-976.

Beatty, R. P., Ritter, J. R., 1986. Investment banking, reputation and the underpricing of Initial public offerings. Journal of Financial Economics 15. 211-232.

Beatty, R. P., Welch, I., 1996. Issuer expences and legal liability in initial public offerings. Journal of Law and Economics 39. 545-602.

Benveniste, L. M., Ljungqvist, A. P., Wilhelm, W. J., Yu, X., 2003. Evidence of information spillovers in the production of investment banking services. Journal of Finance 58. 577-608.

Benveniste, L. M., Spindt, P. A., 1989. How investment bankers determine the offer price and allocation of new issues. Journal of Financial Economics 24. 343-362.

Benveniste, L. M., Wilhelm, W. J., 1990. A comparative analysis of IPO proceeds under alternative regulatory environments. Journal of Financial Economics 28. 173-208.

Biais, B., Faugeron, A. M., 2002. IPO auctions : English, Dutch, ... French and Internet. Journal of Financial Intermediation 11. 9-36.

Boehmer, E., Fishe, R. P. H., 2001. Equilibrium rationing in initial public offerings of equity. Working Paper. University of Miami. 
Bottazzi, L., Da Rin, M., 2002. Europe’s ‘new’ stock markets. CEPR Discussion Paper No. 3521.

Bradley, D., Jordan, B., 2002. Partial adjustment to public information and IPO underpricing. Journal of Financial and Quantitative Analysis 37. 595-616.

Brailsford, T., Heaney, R. A., Powell, J. G., Shi, J., 2000. Hot and cold IPO markets: Identification using a regime switching Model. Multinational Finance Journal 4. 35-68.

Brounen, D., Eichholtz, P., 2002. Initial public offerings: Evidence from the British, French and Swedish property share markets. Journal of Real Estate Finance and Economics 24. 103-117.

Burghof, H.-P., Hunger, A., 2004. Access to stock markets for small and medium-sized growth firms: The temporary success and ultimate failure of Germany's Neuer Markt. Working Paper. Munich University.

Carter, R. B., Dark, F. H., Singh, A. K., 1998. Underwriter reputation, initial returns, and the long-run performance of IPO stocks. Journal of Finance 53. 285-311.

Carter, R. B., Manaster, S., 1990. Initial public offerings and underwriter reputation. Journal of Finance 45. 1045-1067.

Chemmanur, T. J., 1993. The pricing of initial public offers: A dynamic model with information production. Journal of Finance 48. 285-304.

Cornelli, F., Goldreich, D., 2001. Bookbuilding and strategic allocation. Journal of Finance 56. 23372369.

Cornelli, F., Goldreich, D., 2002. Bookbuilding: How informative is the orderbook? Working Paper. London Business School.

Daniel, K., 2002. Discussion of 'Why Don't Issuers Get Upset About Leaving Money on the Table in IPOs?'. The Review of Financial Studies 15. 445-454.

Dorn, D., 2003. Does sentiment drive the retail demand for IPOs? Working Paper. Drexel University.

Ellis, K., Michaely, R., O'Hara, M., 2000. When the underwriter is the market maker : An examination of trading in the IPO aftermarket. Journal of Finance 55. 1039-1074.

Erhardt, O., Stehle, R., 1999. Renditen bei Börseneinführungen am deutschen Kapitalmarkt. Zeitschrift für Betriebswirtschaft 69. 1395-1422.

Giudici, G., Roosenboom, P., 2002. Pricing initial public offerings on 'new' European stock markets. Working Paper. Università degli Studi di Bergamo.

Grinblatt, M., Hwang, C., 1989. Signalling and the pricing of new issues. Journal of Finance 44. 393420.

Habib, M., Ljungqyist, A., 2001. Underpricing and entrepreneurial wealth losses in IPOs: Theory and evidence. Review of Financial Studies 14. 433-458.

Hanley, K. W., 1993. The underpricing of initial public offerings and the partial adjustment phenomenon. Journal of Financial Economics 34. 231-250.

Hanley, K. W., Kumar, A. A. and Seguin, P., 1993. Price stabilization of new issues. Journal of Finance 44. 393-420.

Hansen, R. S., Fuller, B. R. and Janjigian, V., 1987. The over-allotment option and equity financing 
flotation costs: An empirical investigation. Financial Management 20. 24-34.

Hansson, B., Ljungqvist, A. P., 1992. Mispricing of initial public offerings - Evidence from Germany. Working Paper. University of Lund.

Helwege, J., Liang, N., 2002. Initial public offerings in hot and cold markets. Working Paper. Ohio State University.

Hoffmann-Burchardi, U., 2001. Clustering of initial public offerings, information revelation and underpricing. European Economic Review 45. 353-383.

Hunger, A., 2003. Market segmentation and IPO-underpricing: The German experience. Working Paper 02/2003. Munich University.

Ibbotson, R. G., 1975. Price performance of common stock new issues. Journal of Financial Economics 2. 235-272.

Ibbotson, R. G., Jaffe, J. F., 1975. 'Hot issue' markets. Journal of Finance 30. 1027-1042.

Jindra, J., 2000. Seasoned equity offerings, overvaluation, and timing. Working Paper. Ohio State University.

Kaserer, C., Kempf, V., 1995. Das Underpricing-Phänomen am deutschen Kapitalmarkt und seine Ursachen. Zeitschrift für Bankrecht und Bankwirtschaft 7. 45-65.

Keloharju, M., 1993. The winner's curse, legal liability, and the long-run price performance of initial public offerings in Finland. Journal of Financial Economics 28. 251-277.

Kennedy, P., 1996. A guide to econometrics. $3^{\text {rd }}$ edition. Blackwell Publishers Ltd. Oxford. UK.

Kim, M., Ritter J. R., 1999. Valuing IPOs. Journal of Financial Economics 53 (3). 409-437.

Kiss, I., Stehle, R., 2002. Underpricing and Long-Term Performance of Initial Public Offerings at Germany's Neuer Markt, 1997 - 2001. Working Paper. Humboldt Universität zu Berlin.

Klein, P. G., Zoeller, K., 2003. Universal banking and conflicts of interest: Evidence from Germany initial public offerings. Working Paper No. 2003-06. University of Missouri - Columbia.

Koh, F., Walter, T., 1989. A direct test of Rock's model of the pricing of unseasoned issues. Journal of Financial Economics 23, 251-272.

Krigman, L., Shaw, W. H., Womack, K. L., 1999. The persistence of IPO mispricing and the predictive power of flipping. Journal of Finance 54. 1015-1044.

Lee, C. M. C., Shleifer, A., Thaler, R. H., 1991. Investor sentiment and the closed-end fund puzzle. Journal of Finance 46. 75-109.

Lee, P. J., Taylor, S. L., Walter, T. S., 1999. IPO underpricing explanations: Implications from investor application and allocation schedules. Journal of Financial and Quantitative Analysis 34. 425444.

Lerner, J., 1994. Venture capitalists and the decision to go public. Journal of Financial Economics 35. 293-316.

Ljungqvist, A. P., 1997. Pricing initial public offerings: Further evidence from Germany. European Economic Review 41. 1309-1320. 
Ljungqvist, A. P., Nanda, V., Singh, R., 2003. Hot markets, investor sentiment, and IPO pricing. Working Paper. NYU Stern School of Business.

Ljungqvist, A. P., Wilhelm, W. J., 2003. IPO pricing in the dot-com bubble. Journal of Finance 58. 723-752.

Ljungqvist, A. P., Wilhelm, W. J., 2004. What Makes Issuers Happy? Testing the prospect theory of IPO underpricing. Working Paper. New York University.

Löffler, G., 2000. Zeichnungsrenditen am Neuen Markt: Gleichgewicht oder Ineffizienz?. Working Paper. Universität Frankfurt.

Logue, D. E., 1973. On the pricing of unseasoned equity issues : 1965-1969. Journal of Financial and Quantitative Analysis 8.91-103.

Logue, D. E., Rogalski, R. J., Seward, J. K., Foster-Johnson, L., 2002. What is special about the roles of underwriter reputation and market activities in initial public offerings? Journal of Business $75,213-243$.

Loughran, T., Ritter, J. R., 1995. The new issues puzzle. Journal of Finance 50. 23-51.

Loughran, T., Ritter, J. R., 2002. Why don't issuers get upset about leaving money on the table in IPOs? Review of Financial Studies 15. 413-443.

Loughran, T., Ritter, J. R., 2003. Why has IPO underpricing changed over time? Working Paper. University of Notre Dame.

Loughran, T., Ritter, J. R., Rydqvist, K., 1994. Initial public offerings: International insights. PacificBasin Finance Journal 2. 165-199.

Lowry, M., 2003. Why does IPO volume fluctuate so much? Journal of Financial Economics 67. 3-40.

Lowry, M., Schwert, W., 2002. IPO market cycles: Bubbles or sequential learning. Journal of Finance 57. 1171-1200.

Ma, T., Tsai, P. R., 2001. Are initial return and IPO discount the same thing? A comparison of direct public offerings and underwritten IPOs. Working Paper. National Sun Yat-sen University.

McGuiness, P., 1992. An Examination of the underpricing of initial public offerings in Hong Kong: 1980 - 90. Journal of Business Finance and Accounting 19. 165-186.

Merton, R., 1987. A simple model of capital market equilibrium with Incomplete Information. Journal of Finance 42. 483-510.

Newey, W., West, K., 1987. A simple positive semi-definite, heteroskedasticity and autocorrelation consistent covariance matrix. Econometrica 55. 703-708.

Ng, S., Perron, P., 1995. Unit root t-tests in ARMA models with data-dependent methods for the selections of the truncation lag. Journal of the American Statistical Association 90. 268-281.

Peiró, A., 1999. Skewness in financial returns. Journal of Banking and Finance 23. 847-862.

Purnanandam, A. K., Swaminathan, B., 2002. Are IPOs underpriced? Working Paper. Cornell University.

Rajan, R., Servaes, H., 1995. The effect of market conditions on initial public offerings. Working Paper. University of Chicago. 
Rajan, R., Servaes, H., 1997. Analyst following of initial public offerings. The Journal of Finance 52. 507-530.

Reilly, F. K., 1973. Further evidence on short-run results for new issues investors. Journal of Financial and Quantitative Analysis 8. 83-90.

Ritter, J. R., 1984. The 'Hot issue' market of 1980. Journal of Business 57. 215-240.

Ritter, J. R., 1991. The long-run performance of initial public offerings. Journal of Finance 46. 3-27.

Ritter, J. R., 1998. Initial public offerings. Contemporary Finance Digest 2. 5-30

Ritter, J. R., 2003. Differences between European and American IPO markets. European Journal of Management 9. 421-434.

Ritter, J. R., Welch, I., 2002. A review of IPO activity, pricing, and allocations. Journal of Finance 57. 1795-1828.

Rock, K., 1986. Why new issues are underpriced. Journal of Financial Economics 15. 187-212.

Ruud, J. S., 1993. Underwriter price support and the IPO underpricing puzzle. Journal of Financial Economics 34. 135-151.

Sapusek, A., 2000. Benchmark-sensitivity of IPO long-run performance: An empirical study for Germany. Schmalenbach Business Review 52. 374-405

Schultz, P., 2003. Pseudo market timing and the long-run underperformance of IPOs. Journal of Finance 58. 483-517.

Sherman, A., Titman, S., 2002. Building the IPO order book: Underpricing and participation limits with costly information. Journal of Financial Economics 65. 3-29.

Spatt, C. S., Srivastava, S., 1991. Preplay communication, participation restrictions, and efficiency in initial public offerings. Review of Financial Studies 4. 709-726.

Stehle, R., Ehrhardt, O., Przyborowsky, R., 2000. Long-run performance of German initial public offerings and seasoned equity issues. European Financial Management 6. 173-196.

Stoll, H. R., Curley, A. J., 1970. Small business and the new issues market for equities. Journal of Financial and Quantitative Analysis 5. 309-322.

Tinic, S. M., 1988. Anatomy of Initial Public Offerings of Common Stocks. The Journal of Finance 18. 789-822.

Wasserfallen, W., Wittleder, C., 1994. Pricing initial public offerings. European Economic Review 38. 1505-1517.

Welch, I., 1989. Seasoned offerings, initiation costs, and the underpricing of initial public offerings. Journal of Finance 44. 421-450.

Welch, I., 1992. Sequential sales, learning, and cascades. Journal of Finance 47. 695-732.

White, H., 1980. A heteroskedasticity-consistent covariance matrix estimator and a direct test of heteroskedasticity. Econometrics 48. 817-838. 
Table I

Summary of the proposed explanatory variables

\begin{tabular}{|c|c|c|c|}
\hline \multirow[b]{2}{*}{ Explanatory variable } & \multirow[b]{2}{*}{ Abbreviation } & \multicolumn{2}{|c|}{ Expected impact on underpricing (sign) } \\
\hline & & $\begin{array}{l}\text { Investor sentiment and } \\
\text { demand hypothesis }\end{array}$ & $\begin{array}{c}\text { Ex-ante uncertainty } \\
\text { hypothesis }\end{array}$ \\
\hline Age of the company & Age & + & - \\
\hline Length of the subscription period & $\mathrm{Bbd}$ & - & + \\
\hline Width of the bookbuilding range & Bbw & - & + \\
\hline $\begin{array}{l}\text { Inverse of the company's market } \\
\text { capitalisation at the IPO }\end{array}$ & Marketcap & - & + \\
\hline $\begin{array}{l}\text { Number of completed IPOs prior to the offer } \\
\text { (i.e. IPO cycles) }\end{array}$ & Volume & - & \\
\hline Usage of the Greenshoe & Greenshoe & + & \\
\hline Business climate index & $\mathrm{Bc}$ & + & \\
\hline $\begin{array}{l}\text { Development of the Nemax All Share Index } \\
\text { prior to the IPO }\end{array}$ & Nemax & + & \\
\hline $\begin{array}{l}\text {,Experience' of the Underwriter } \\
\left(1^{\text {st }} \text { quantile }\right)\end{array}$ & Underwriter1 & + & - \\
\hline $\begin{array}{l}\text {,Experience' of the Underwriter } \\
\left.\text { ( } 2^{\text {nd }} \text { quantile }\right)\end{array}$ & Underwriter2 & - & + \\
\hline
\end{tabular}




\section{Table II}

\section{Descriptive statistics about sample firms}

The sample covers the 1997 - 2001 period and 410 firm. The initial public offerings were taken from the Frankfurt Stock Exchange web pages and Factbooks and always double checked with the company's prospectus, homepage or investor relations department, the IPO database of the 'Börsenzeitung' and the IPO database of OnVista. Issue volume is the number of issued shares (and therefore excluding the Greenshoe) multiplied by the issue price. Market capitalization is calculated by multiplying the issue price with the total amount of shares at the time of the IPO. Age is calculated as the time period between the foundation of the company and its issue date. If the firm has gone through mergers or restructuring prior going public, the foundation date of the oldest predecessor has been chosen. Initial return (IRI) is calculated as $\left(\mathrm{P}_{\mathrm{t}} / \mathrm{P}_{\text {offer }}\right)-1$, where $\mathrm{P}_{\text {offer }}$ is the offer price at the end of the bookbuilding period and $\mathrm{P}_{\mathrm{t}}$ is the closing price of the first trading day. The expected offer price is computed as the midpoint of the indicative filing range. Price revision is calculated as the update between the expected offer price and the issue price in percent. Bookbuilding days are calculated as the difference between start and end of the subscription period. The width of the bookbuilding range represents the difference between the upper and lower bound divided by the midpoint. The return of the Nemax All Share index has been calculated as holding period returns for the different time periods, therefore as $\left(\mathrm{P}_{t} / \mathrm{P}_{\mathrm{t}-1}\right)-1$, where $\mathrm{P}_{\mathrm{t}}$ represents the level of the index at the end of the period and $\mathrm{P}_{\mathrm{t}-1}$ the level of the index at the beginning of the period.

\begin{tabular}{|c|c|c|c|c|c|c|c|c|c|}
\hline & & $\begin{array}{l}1997- \\
2001 \\
\end{array}$ & 1997 & 1998 & 1999 & 2000 & $\begin{array}{l}01 / 2000- \\
07 / 2000 \\
\end{array}$ & $\begin{array}{c}08 / 2000- \\
12 / 000 \\
\end{array}$ & 2001 \\
\hline Number of firms & & 410 & 16 & 62 & 165 & 150 & (111) & (39) & 17 \\
\hline Missing firms & & 14 & 10 & 2 & 1 & 0 & (0) & (0) & 1 \\
\hline $\begin{array}{l}\text { Issue volume in } \\
\text { Mill. } €\end{array}$ & $\begin{array}{l}\text { Mean } \\
\text { Median }\end{array}$ & $\begin{array}{l}107.97 \\
36.79\end{array}$ & $\begin{array}{l}57.20 \\
30.10\end{array}$ & $\begin{array}{l}49.87 \\
26.47\end{array}$ & $\begin{array}{l}76.02 \\
35.19\end{array}$ & $\begin{array}{l}169.64 \\
43.78\end{array}$ & $\begin{array}{c}(153.62) \\
(49.18)\end{array}$ & $\begin{array}{c}(215.22) \\
(35.10)\end{array}$ & $\begin{array}{c}133.49 \\
20.22\end{array}$ \\
\hline $\begin{array}{l}\text { Market capitalisa- } \\
\text { tion in Mill. } €\end{array}$ & $\begin{array}{c}\text { Mean } \\
\text { Median }\end{array}$ & $\begin{array}{l}374.27 \\
125.50\end{array}$ & $\begin{array}{c}252.01 \\
92.04\end{array}$ & $\begin{array}{c}143.69 \\
82.58\end{array}$ & $\begin{array}{l}240.66 \\
124.80\end{array}$ & $\begin{array}{l}620.87 \\
153.33\end{array}$ & $\begin{array}{l}(652.73) \\
(160.00)\end{array}$ & $\begin{array}{l}(530.16) \\
(134.75)\end{array}$ & $\begin{array}{c}451.23 \\
64.40\end{array}$ \\
\hline Age of the company & $\begin{array}{c}\text { Mean } \\
\text { Median }\end{array}$ & $\begin{array}{l}17.59 \\
10.32\end{array}$ & $\begin{array}{l}35.75 \\
11.68\end{array}$ & $\begin{array}{l}19.94 \\
14.92\end{array}$ & $\begin{array}{l}19.55 \\
10.05\end{array}$ & $\begin{array}{c}12.13 \\
9.53\end{array}$ & $\begin{array}{c}(11.80) \\
(9.66)\end{array}$ & $\begin{array}{c}(13.05) \\
(9.40)\end{array}$ & $\begin{array}{l}21.10 \\
16.28\end{array}$ \\
\hline IR1(median) & $\begin{array}{l}\text { Mean } \\
\text { Median }\end{array}$ & $\begin{array}{l}44.47 \% \\
16.40 \%\end{array}$ & $\begin{array}{l}38.11 \% \\
19.84 \%\end{array}$ & $\begin{array}{l}64.10 \% \\
38.36 \%\end{array}$ & $\begin{array}{l}40.89 \% \\
13.73 \%\end{array}$ & $\begin{array}{l}45.41 \% \\
19.25 \%\end{array}$ & $\begin{array}{l}(54.12 \%) \\
(25.63 \%)\end{array}$ & $\begin{array}{c}(20.63 \%) \\
(5.17 \%)\end{array}$ & $\begin{array}{l}5.32 \% \\
1.43 \%\end{array}$ \\
\hline Price Revision & $\begin{array}{l}\text { Mean } \\
\text { Median }\end{array}$ & $\begin{array}{l}3.92 \% \\
6.98 \%\end{array}$ & $\begin{array}{l}7.01 \% \\
8.38 \%\end{array}$ & $\begin{array}{l}8.23 \% \\
7.13 \%\end{array}$ & $\begin{array}{l}3.91 \% \\
6.90 \%\end{array}$ & $\begin{array}{l}2.50 \% \\
6.82 \%\end{array}$ & $\begin{array}{l}(4.80 \%) \\
(7.32 \%)\end{array}$ & $\begin{array}{l}(-4.06 \%) \\
(-3.61 \%)\end{array}$ & $\begin{array}{l}-2.06 \% \\
-3.85 \%\end{array}$ \\
\hline Bookbuidling days & $\begin{array}{l}\text { Mean } \\
\text { Median }\end{array}$ & $\begin{array}{l}5.87 \\
5.00\end{array}$ & $\begin{array}{l}5.69 \\
3.50\end{array}$ & $\begin{array}{l}4.92 \\
3.00\end{array}$ & $\begin{array}{l}5.69 \\
5.00\end{array}$ & $\begin{array}{l}6.35 \\
6.00\end{array}$ & $\begin{array}{l}(6.09) \\
(5.00)\end{array}$ & $\begin{array}{l}(7.10) \\
(7.00)\end{array}$ & $\begin{array}{l}7.06 \\
7.00\end{array}$ \\
\hline Bookbuilding range & $\begin{array}{l}\text { Mean } \\
\text { Median }\end{array}$ & $\begin{array}{l}17.58 \% \\
16.84 \%\end{array}$ & $\begin{array}{l}17.04 \% \\
17.11 \%\end{array}$ & $\begin{array}{l}15.71 \% \\
15.03 \%\end{array}$ & $\begin{array}{l}17.21 \% \\
16.22 \%\end{array}$ & $\begin{array}{l}18.30 \% \\
17.34 \%\end{array}$ & $\begin{array}{l}(17.10 \%) \\
(16.95 \%)\end{array}$ & $\begin{array}{l}(21.69 \%) \\
(18.87 \%)\end{array}$ & $\begin{array}{l}22.18 \% \\
22.61 \%\end{array}$ \\
\hline $\begin{array}{l}\text { Return of Nemax All } \\
\text { Share Index }\end{array}$ & & $114.58 \%$ & $97.44 \%$ & $173.86 \%$ & $66.23 \%$ & $-39.55 \%$ & $12.32 \%$ & $-45.76 \%$ & $-61.39 \%$ \\
\hline
\end{tabular}




\section{Table III}

\section{Underpricing by industry groups}

The sample covers the 1997 - 2001 period and 410 firm. The initial public offerings were taken from the Frankfurt Stock Exchange web pages and Factbooks and always double checked with the company's prospectus, homepage or investor relations department, the IPO database of the 'Börsenzeitung' and the IPO database of OnVista. Industry classification (C-DAX classification) is taken from the Frankfurt Stock Exchange web pages or where not available from OnVista, 'Börsenzeitung', and Comdirect web pages. Initial return (IRI) is calculated as $\left(\mathrm{P}_{t} / \mathrm{P}_{\text {offer }}\right)-1$, where $\mathrm{P}_{\text {offer }}$ is the offer price at the end of the bookbuilding period and $\mathrm{P}_{\mathrm{t}}$ is the closing price of the first trading day. $I R$ negative states the number or IPOs having zero or negative first day returns. As in some groups only on firm went public the standard deviation could not be calculated and therefore 'n.a.' is stated.

\begin{tabular}{lccccccc}
\hline & $\begin{array}{c}\text { Number of } \\
\text { IPOs }\end{array}$ & Min & Maximum & Median & Mean & $\begin{array}{c}\text { Standard } \\
\text { deviation }\end{array}$ & $\begin{array}{c}\text { IR } \\
\text { negative? }\end{array}$ \\
\hline Automobile & 6 & -0.01 & 0.76 & 0.07 & 0.18 & 0.29 & 1 \\
Banks & 3 & 0.14 & 1.38 & 0.43 & 0.65 & 0.65 & 0 \\
Basic resources & 1 & 0.03 & 0.03 & 0.03 & 0.03 & n.a. & 0 \\
Chemicals & 2 & 0.01 & 0.71 & 0.36 & 0.36 & 0.49 & 0 \\
Construction & 1 & 0.00 & 0.00 & 0.00 & 0.00 & n.a. & 0 \\
Consumer-cyclical & 5 & -0.04 & 0.09 & 0.00 & 0.01 & 0.05 & 2 \\
Financial services & 17 & -0.08 & 1.66 & 0.28 & 0.56 & 0.66 & 4 \\
Food \& beverages & 1 & 0.01 & 0.01 & 0.01 & 0.01 & n.a. & 0 \\
Industrial & 20 & -0.11 & 0.76 & 0.04 & 0.16 & 0.25 & 6 \\
Machinery & 6 & -0.08 & 0.16 & 0.00 & 0.01 & 0.08 & 3 \\
Media & 49 & -0.22 & 3.56 & 0.20 & 0.62 & 0.87 & 13 \\
Pharma \& health & 35 & -0.09 & 2.46 & 0.08 & 0.34 & 0.57 & 8 \\
Retail & 8 & -0.16 & 1.66 & 0.17 & 0.39 & 0.61 & 2 \\
Software & 147 & -0.30 & 3.52 & 0.26 & 0.50 & 0.71 & 32 \\
Technology & 80 & -0.18 & 4.44 & 0.26 & 0.46 & 0.69 & 15 \\
Telecommunications & 19 & -0.28 & 4.04 & 0.27 & 0.51 & 0.94 & 3 \\
Transp. \& logistics & 9 & -0.07 & 0.69 & 0.02 & 0.10 & 0.23 & 3 \\
Utilities & 1 & 0.00 & 0.00 & 0.00 & 0.00 & n.a. & 0 \\
\hline
\end{tabular}




\section{Table IV}

\section{OLS industry and stock market segment regression}

The sample covers the $1997-2001$ period and 410 firm. The initial public offerings were taken from the Frankfurt Stock Exchange web pages and Factbooks and always double checked with the company's prospectus, homepage or investor relations department, the IPO database of the 'Börsenzeitung' and the IPO database of OnVista. Industry classification (C-DAX classification) is taken from the Frankfurt Stock Exchange web pages or where not available from OnVista, 'Börsenzeitung', and Comdirect web pages. Initial return (IRl) is calculated as $\ln \left(\mathrm{P}_{\mathrm{t}} / \mathrm{P}_{\text {offer }}\right)$, where $\mathrm{P}_{\mathrm{t}}$ is the first day closing price and $\mathrm{P}_{\text {offer }}$ the offer price after the bookbuilding period, respectively. The industry dummies take the value one if the firm belongs to the particular C-DAX industry classification and zero otherwise. The dummies 'Neuer Markt' (nm), SMAX (smax), and 'Amtlicher Handel' (ah) take the value one if the firm went public on this specific stock market segment, respectively, and zero otherwise. We exclude industries with less than 4 IPOs. The Models are estimated using OLS and the standard errors are adjusted for heteroskedasticity of the error term using White's (1980) methodology. The results of the t-statistics (two-sided test) are denoted in brackets. The reported F-statistic is for the significance of the proposed models. We use ***,**, and * to denote significance at the one percent, five percent and ten percent level, respectively. The Number of observations is 410 .

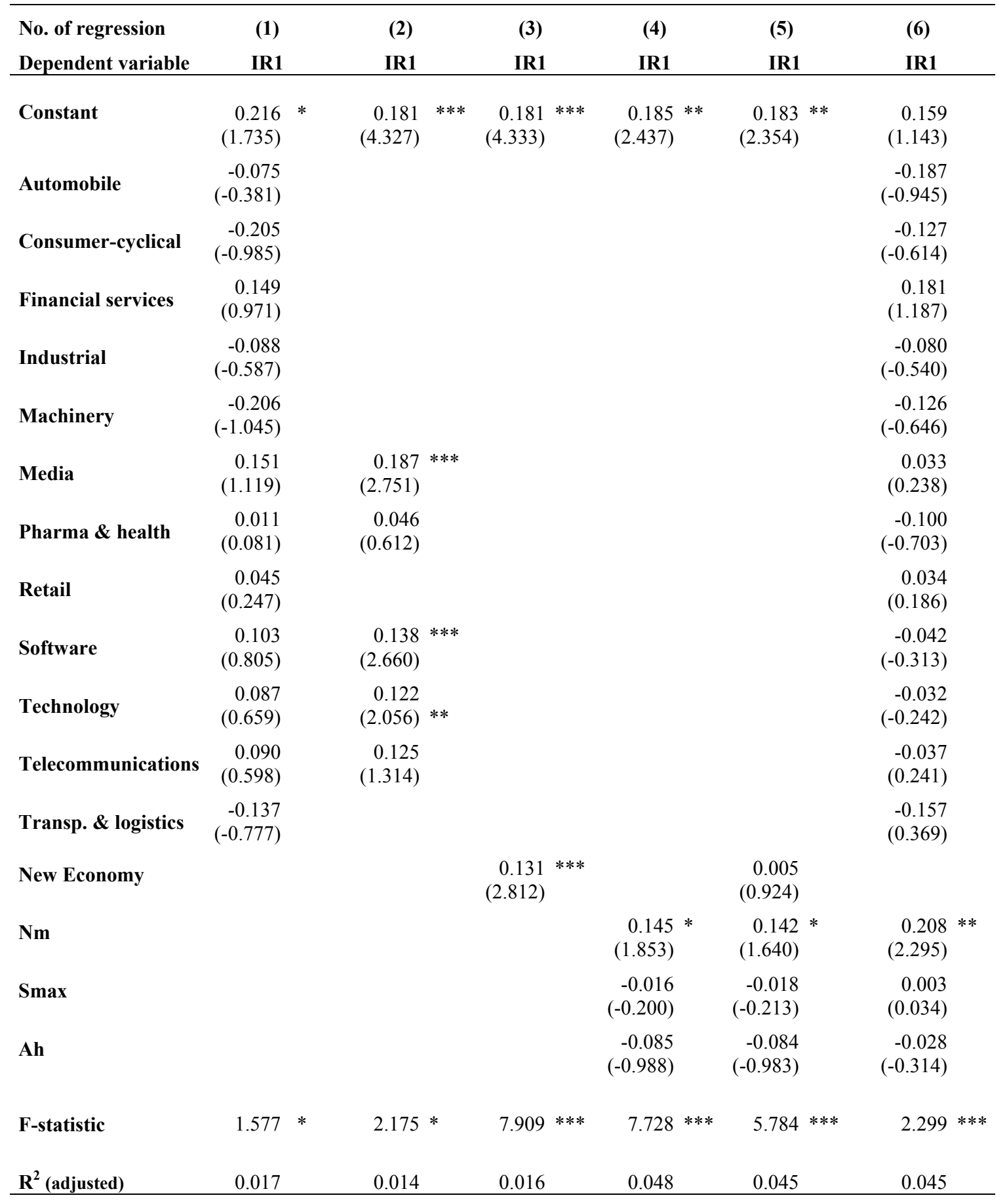




\section{FIGURE I}

\section{Historgramm of underpricing and IPO activity}

The sample covers the 1997 - 2001 period and 410 firm. The initial public offerings were taken from the Frankfurt Stock Exchange web pages and Factbooks and always double checked with the company's prospectus, homepage or investor relations department, the IPO database of the 'Börsenzeitung' and the IPO database of OnVista. Industry classification (C-DAX classification) is taken from the Frankfurt Stock Exchange web pages or where not available from OnVista, 'Börsenzeitung', and Comdirect web pages. Initial return (IR1) is calculated as $\left(\mathrm{P}_{\mathrm{t}} / \mathrm{P}_{\text {offer }}\right)-1$, where $\mathrm{P}_{\text {offer }}$ is the offer price at the end of the bookbuilding period and $\mathrm{P}_{\mathrm{t}}$ is the closing price of the first trading day. Number of IPOs is calculated as the number of IPOs. Values are quarterly averages calculated using equal weights.

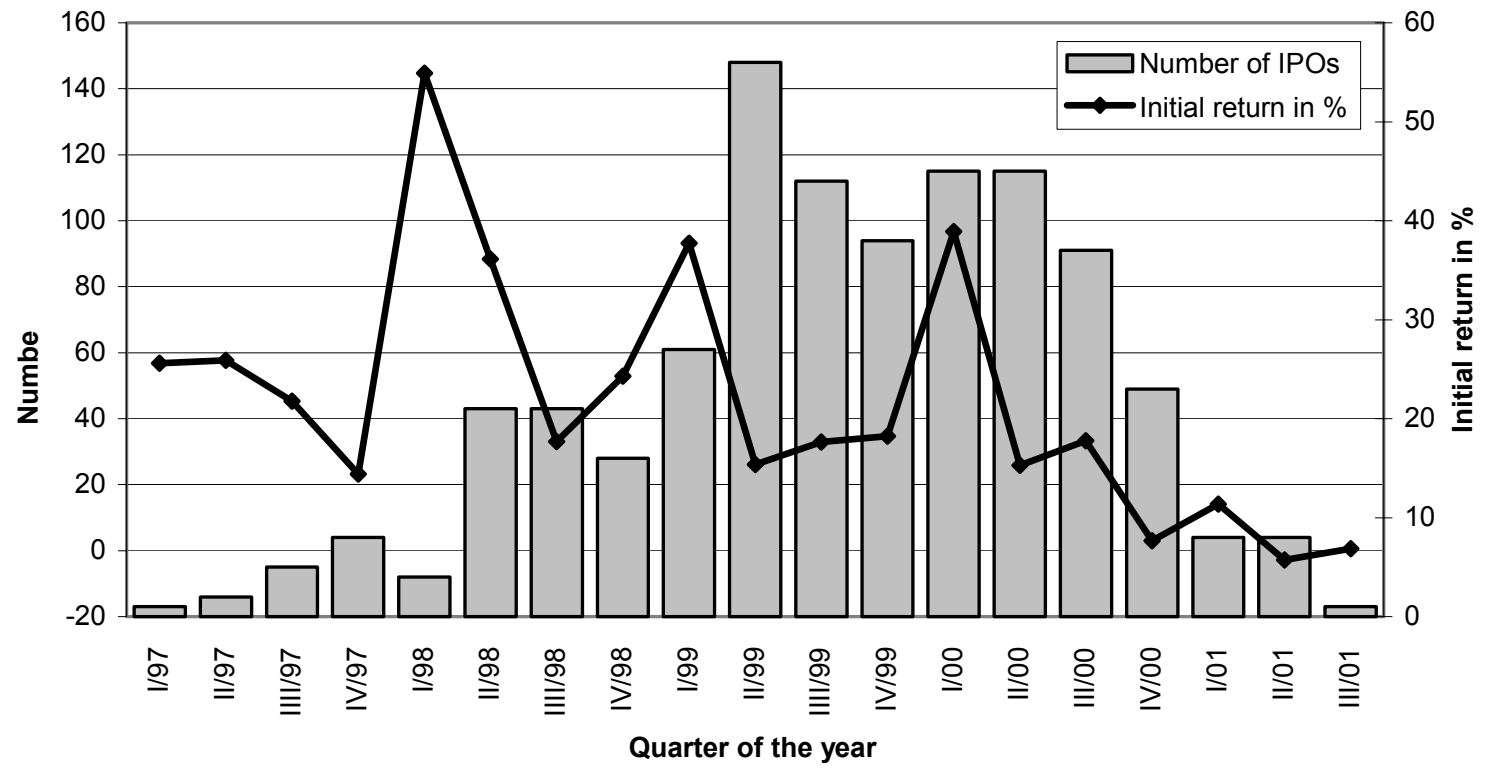




\section{Table V}

Seasonality in IPO volume and underpricing

The sample covers the $1997-2001$ period and 410 firm. The initial public offerings were taken from the Frankfurt Stock Exchange web pages and Factbooks and always double checked with the company's prospectus, homepage or investor relations department, the IPO database of the 'Börsenzeitung' and the IPO database of OnVista. The dependent variable in regression (7), (9), and (11) is the initial return at the first trading day (IR1), measured as $\left(\mathrm{P}_{t} / \mathrm{P}_{\text {offer }}\right)$, where $\mathrm{P}_{\text {offer }}$ is the offer price at the end of the bookbuilding period and $\mathrm{P}_{t}$ is the closing price of the first trading day. The dependent variable in regression (8), (10), and (12) is the IPO volume (volume), measured as the number of IPOs. The quarterly averages have been calculated using equal weights. Dummy1, dummy2 and dummy 3 are coded 1 for the first, second and third quarter of the year, respectively, and zero otherwise. Trend takes the value 1 in the first quarter of 1997 up to 19 during the third quarter in 2001. The Models are estimated using OLS and adjusted for serial correlation of the error term using the consistent covariance developed by Newey and West (1987). The results of the t-statistics (two-sided test) is denoted in brackets. The reported F-statistic is for the significance of the proposed models. We use $* * *, * *$, and $*$ to denote significance at the one percent, five percent and ten percent level, respectively. The Number of observations is 19.

\begin{tabular}{|c|c|c|c|c|c|c|}
\hline No. of regression & (7) & (8) & (9) & (10) & (11) & (12) \\
\hline $\begin{array}{l}\text { Dependent } \\
\text { variable }\end{array}$ & IR1 & Volume & IR1 & Volume & IR1 & Volume \\
\hline \multirow{3}{*}{ Constant } & 0.083 & -0.443 & -0.069 & -5.500 & 0.349 & -10.703 \\
\hline & $(0.171)$ & $(-0.043)$ & $(0.428)$ & $(-1.102)$ & $(0.934)$ & $(1.075)$ \\
\hline & -0.018 & 1.440 & & & -0.083 & 2.231 \\
\hline \multirow[t]{2}{*}{ Trend } & $(-0.172)$ & $(0.651)$ & & & $(-1.157)$ & $(1.168)$ \\
\hline & 0.001 & -0.107 & & & 0.003 & -0.143 \\
\hline \multirow[t]{2}{*}{ Trend $^{2}$} & $(0.112)$ & $(-1.040$ & & & $(1.027)$ & $(-1.603)$ \\
\hline & & & 0.649 & 5.250 & 0.660 & 6.013 \\
\hline \multirow{2}{*}{ Dummy1 } & & & $(2.839) * *$ & $(0.744)$ & $(2.838) * *$ & $(0.969)$ \\
\hline & & & -0.351 & 14.90 & -0.392 & 16.610 \\
\hline \multirow[t]{2}{*}{ Dummy2 } & & & $(-1.619)$ & $(2.225) * *$ & $(-1.753)$ & $(2.783) * *$ \\
\hline & & & -0.031 & 0.700 & -0.061 & 3.173 \\
\hline Dummy3 & & & $(-0.143)$ & $(0.105)$ & $(-0.272)$ & $(0.530)$ \\
\hline F-statistic & 0.048 & 1.984 & $7.271 * * *$ & 2.268 & $4.554 * *$ & $3.012 *$ \\
\hline $\mathbf{R}^{2}$ (adjusted) & -0.126 & 0.104 & 0.525 & 0.183 & 0.511 & 0.372 \\
\hline
\end{tabular}




\section{Table VI}

\section{Hot issue market}

The sample covers the 1997 - 2001 period and 410 firm. The initial public offerings were taken from the Frankfurt Stock Exchange web pages and Factbooks and always double checked with the company's prospectus, homepage or investor relations department, the IPO database of the 'Börsenzeitung' and the IPO database of OnVista. IPO volume, volume, is measured as in Ibbotson/Jaffe (1975) as the number of IPOs per month. The initial return (IRI) is measured as $\mathrm{P}_{\mathrm{t}} / \mathrm{P}_{\text {offer }}$, where $\mathrm{P}_{\text {offer }}$ is the offer price at the end of the bookbuilding period and $\mathrm{P}_{\mathrm{t}}$ is the closing price of the first trading day. The monthly averages have been calculated using equal weights. Regression (13) is estimated using OLS and adjusted for serial correlation of the error term using the consistent covariance developed by Newey and West (1987). The results of the t-statistics (two-sided test) is denoted in brackets. The reported F-statistic is for the significance of the proposed model. Regressions (14) to (17) are OLS estimations of an unrestricted VAR. The lag length for (16) and (17) has been chosen using the Akaike Information Criteria. We use ***,**, and * to denote significance at the one percent, five percent and 10 percent level, respectively.

\begin{tabular}{|c|c|c|c|c|}
\hline No. of regression & (13) & (14) & (15) & (16) \\
\hline $\begin{array}{l}\text { Estimation } \\
\text { method } \\
\text { Dependent } \\
\text { variable }\end{array}$ & $\begin{array}{c}\text { OLS } \\
\text { Volume }\end{array}$ & $\begin{array}{c}\text { OLS - VAR } \\
\text { Volume }\end{array}$ & $\begin{array}{c}\text { OLS - VAR } \\
\text { IR1 }\end{array}$ & $\begin{array}{c}\text { OLS - VAR } \\
\text { IR1 }\end{array}$ \\
\hline Constant & $\begin{array}{r}-2.070 \\
(-1.185)\end{array}$ & $\begin{array}{l}-4.538 * * \\
(2.211)\end{array}$ & $\begin{array}{c}0.500 \\
(1.869)\end{array}$ & $\begin{array}{l}0.500 * * \\
(2.008)\end{array}$ \\
\hline Volume $_{t-1}$ & & $\begin{array}{l}0.237 \\
(1.799)\end{array}$ & $\begin{array}{r}0.008 \\
(0.530)\end{array}$ & \\
\hline Volume $_{t-2}$ & & $\begin{array}{r}0.034 \\
(0.251)\end{array}$ & $\begin{array}{r}-0.008 \\
(-0.506)\end{array}$ & \\
\hline Volume $_{t-3}$ & & $\begin{array}{r}0.007 \\
(0.050)\end{array}$ & $\begin{array}{r}0.007 \\
(0.470)\end{array}$ & \\
\hline Volume $_{t-4}$ & & $\begin{array}{l}0.407 \text { *** } \\
(3.329)\end{array}$ & $\begin{array}{r}0.001 \\
(0.037)\end{array}$ & \\
\hline IR1 $_{t-1}$ & $\begin{array}{r}1.245 \\
(0.963)\end{array}$ & $\begin{array}{r}0.230 \\
(0.189)\end{array}$ & $\begin{array}{l}0.612 \text { *** } \\
(4.153)\end{array}$ & $\begin{array}{l}0.616^{* * * *} \\
(4.365)\end{array}$ \\
\hline IR1 $1_{t-2}$ & $\begin{array}{r}1.855 \\
(1.509)\end{array}$ & $\begin{array}{r}2.431 \\
(1.710)\end{array}$ & $\begin{array}{r}-0.148 \\
(-0.861)\end{array}$ & $\begin{array}{r}-0.143 \\
(-0.871)\end{array}$ \\
\hline IR1 $1_{t-3}$ & $\begin{array}{l}3.993 \text { *** } \\
(3.006)\end{array}$ & $\begin{array}{r}1.782 \\
(1.271)\end{array}$ & $\begin{array}{r}0.112 \\
(0.660)\end{array}$ & $\begin{array}{r}0.134 \\
(0.829)\end{array}$ \\
\hline IR1 $_{t-4}$ & & $\begin{array}{r}0.701 \\
(0.530)\end{array}$ & $\begin{array}{r}-0.019 \\
(-0.119\end{array}$ & $\begin{array}{r}-0.002 \\
(-0.011)\end{array}$ \\
\hline $\mathbf{R}^{2}$ (adjusted) & 0.233 & 0.516 & 0.214 & 0.264 \\
\hline \multicolumn{5}{|l|}{ Granger F-tests } \\
\hline Lagged Volume & & & 0.727 & \\
\hline Lagged IR1 & & $11.824 * *$ & & \\
\hline Lagged varibles & $6.667 * * *$ & $8.329 * * *$ & $2.868 * * *$ & $5.936 * * *$ \\
\hline Sample size & 57 & 56 & 56 & 56 \\
\hline
\end{tabular}


Figure II

Impulse Responses in the volume and IR1 VAR
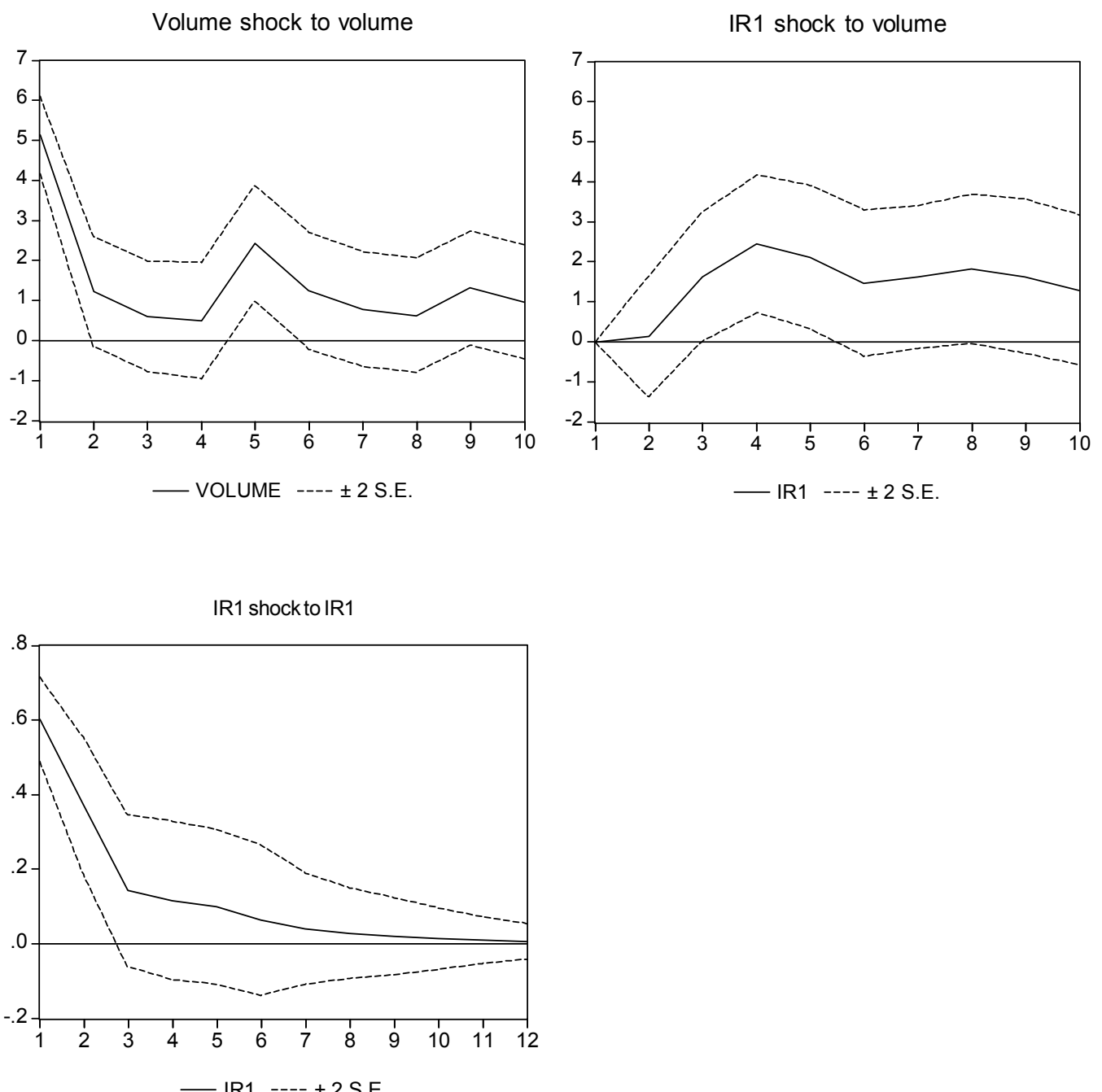
Figure III

\section{Histogram of first day returns}

The sample covers the 1997 - 2001 period and 410 firm. The initial public offerings were taken from the Frankfurt Stock Exchange web pages and Factbooks and always double checked with the company's prospectus, homepage or investor relations department, the IPO database of the 'Börsenzeitung' and the IPO database of OnVista. The initial return (IR1) returns are calculated as $\ln \left(\mathrm{P}_{t} / \mathrm{P}_{\text {offer }}\right)$, where $\mathrm{P}_{\text {offer }}$ is the offering price at the end of the bookbuilding range and $\mathrm{P}_{t}$ is the first day closing price.

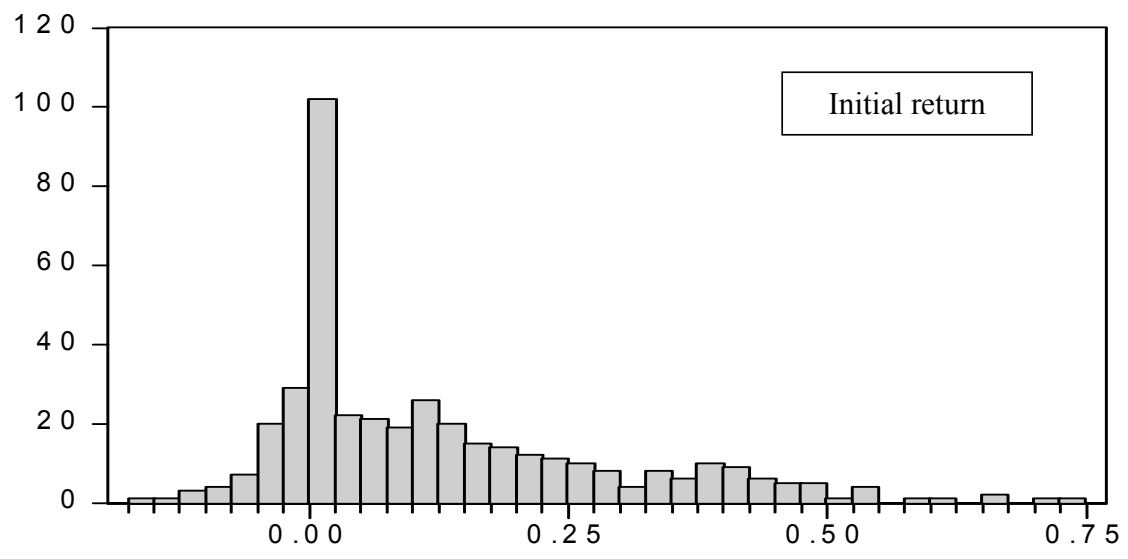


Table VII

Characteristics of the holding period returns for the first 30 trading days

The sample covers the $1997-2001$ period and 410 firm. The initial public offerings were taken from the Frankfurt Stock Exchange web pages and Factbooks and always double checked with the company's prospectus, homepage or investor relations department, the IPO database of the 'Börsenzeitung' and the IPO database of OnVista. Initial returns $\left(I R_{t}\right)$ are calculated as $\ln \left(\mathrm{P}_{\mathrm{t}} / \mathrm{P}_{\text {offer }}\right.$ ), where $\mathrm{P}_{\mathrm{t}}$ is the market price at time $\mathrm{t}$, which ranges from 0 (offer price at day 1) to 30 (closing price at day 30 ), and $\mathrm{P}_{\text {offer }}$ is the offer price at the end of the bookbuilding period.

\begin{tabular}{lcccccccc}
\hline & $\mathbf{I R}_{\mathbf{0}}$ & $\mathbf{I R}_{\mathbf{1}}$ & $\mathbf{I R}_{\mathbf{5}}$ & $\mathbf{I R}_{\mathbf{1 0}}$ & $\mathbf{I R}_{\mathbf{1 5}}$ & $\mathbf{I R}_{\mathbf{2 0}}$ & $\mathbf{I R}_{\mathbf{2 5}}$ & $\mathbf{I R}_{\mathbf{3 0}}$ \\
\hline Mean & 0.1178 & 0.1230 & 0.1182 & 0.1165 & 0.1150 & 0.1166 & 0.1158 & 0.1203 \\
Median & 0.0492 & 0.0653 & 0.0676 & 0.0690 & 0.0706 & 0.0657 & 0.0726 & 0.0686 \\
Maximum & 0.7270 & 0.7360 & 0.8171 & 0.8092 & 0.8692 & 0.8239 & 0.9208 & 0.9453 \\
Minimum & -0.1390 & -0.1549 & -0.2386 & -0.2440 & -0.3163 & -0.3130 & -0.4583 & -0.4534 \\
Std. dev. & 0.1602 & 0.1632 & 0.1796 & 0.1919 & 0.2036 & 0.2035 & 0.2159 & 0.2272 \\
Skewness & 1.3166 & 1.1848 & 1.0847 & 0.9518 & 1.0033 & 0.8643 & 0.8145 & 0.7655 \\
Kurtosis & 4.0547 & 3.8551 & 4.0364 & 3.6608 & 4.0820 & 3.7101 & 3.6958 & 3.5980 \\
\hline
\end{tabular}




\section{Figure IV}

\section{Migration of holding returns of IPOs with zero or negative initial return}

The sample covers the 1997 - 2001 period and 410 firm. The initial public Offerings were taken from the Frankfurt Stock Exchange web pages and Factbooks and always double checked with the company's prospectus, homepage or investor relations department, the IPO database of the 'Börsenzeitung' and the IPO database of OnVista. The initial return $(I R(t))$ is calculated as $\ln \left(\mathrm{P}_{\mathrm{t}} / \mathrm{P}_{\text {offer }}\right)$, where $\mathrm{P}_{\mathrm{t}}$ is the market price at time $\mathrm{t}$, which ranges from 0 (offer price at day 1) to 30 (closing price at day 30 ), and $\mathrm{P}_{\text {offer }}$ is the offer price at the end of the bookbuilding period. The analysis is based on 120 IP0s with IR0 or IR1 being zero or negative.

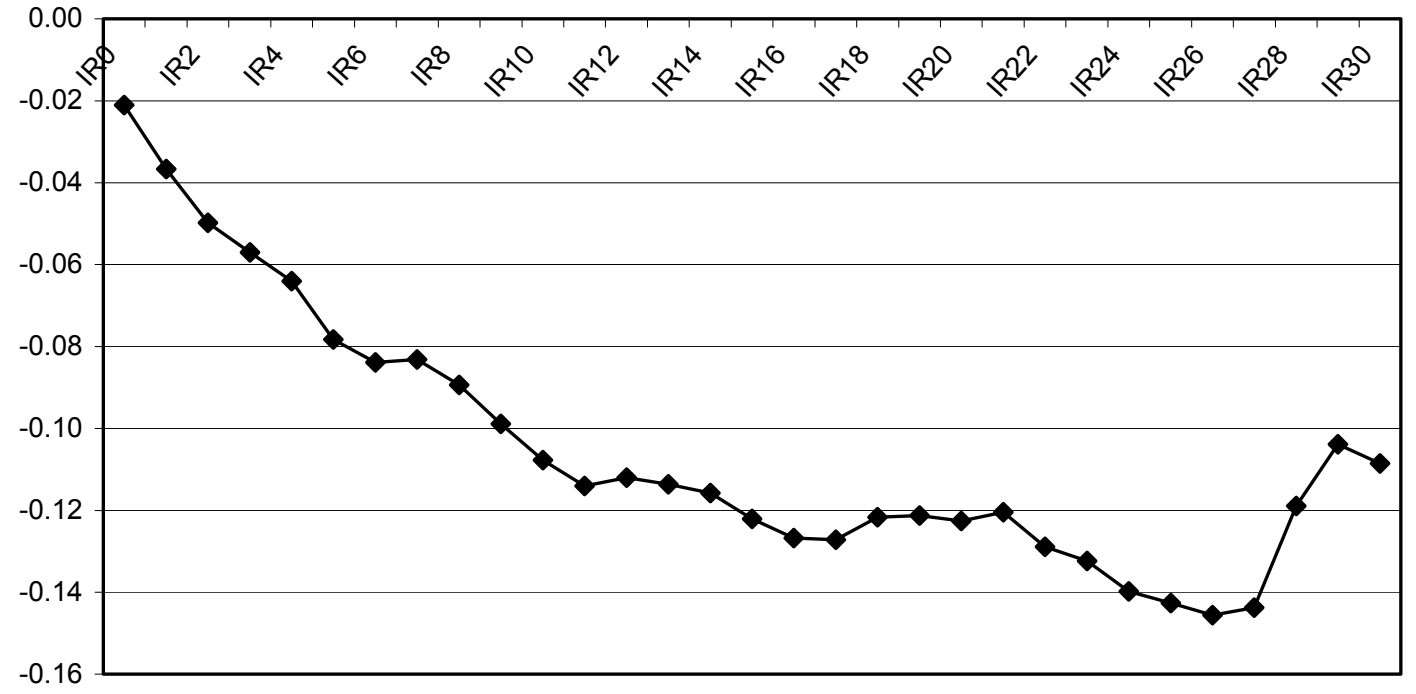

Holding period 


\section{Figure V}

Migration of holding returns of IPOs with zero or negative initial return (IR1) and the use of the Greenshoe option

The sample covers the 1997 - 2001 period and 410 firm The Initial Public Oofferings were taken from the Frankfurt Stock Exchange web pags and Factboos and always double checked with the compans prospectus, company's homepage or investor relations department, the IPO database of the 'Börsenzeitung' and the IPO database of OnVista. The initial return $(I R(t))$ is calculated as $\ln \left(\mathrm{P}_{\mathrm{t}} / \mathrm{P}_{\text {offer }}\right)$, where $\mathrm{P}_{\mathrm{t}}$ is the market price at time $\mathrm{t}$, which ranges from 0 (offer price at day 1 ) to 30 (closing price at day 30), and $\mathrm{P}_{\text {offer }}$ is the offer price at the end of the bookbuilding period. The analysis is based on firm with IR0 or IR1 being zero or nagative. The Greenshoe has been used for 42 IPO and not used for 69 IPOs.

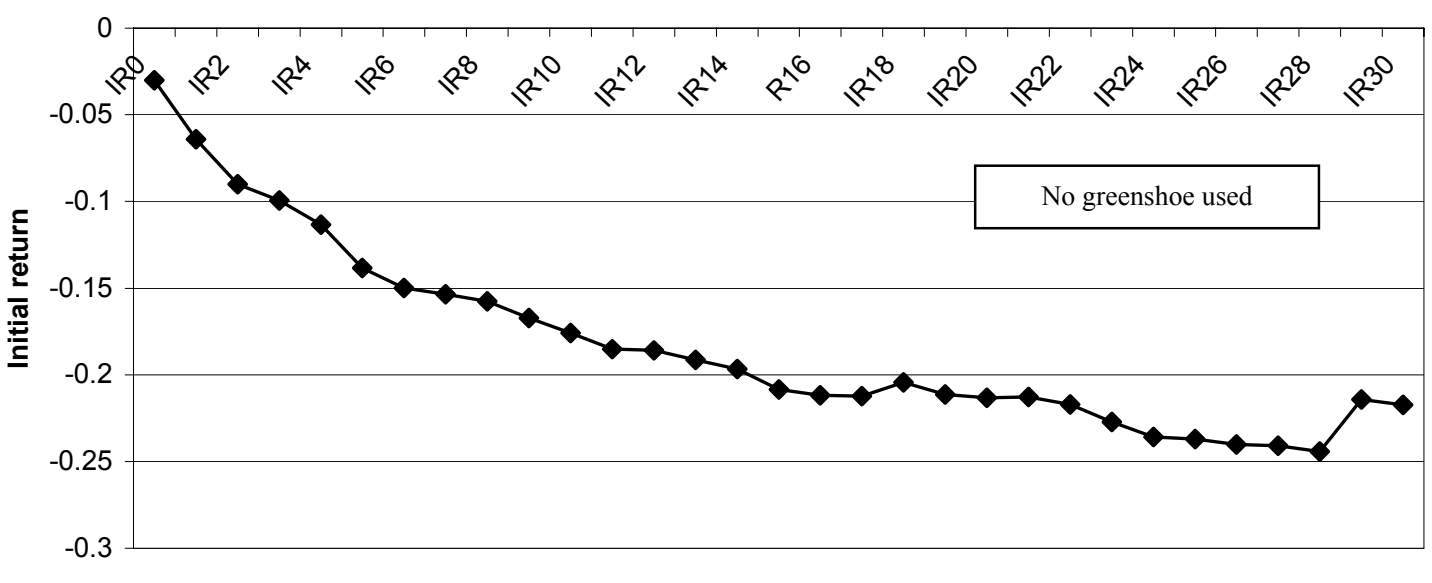

Holding period

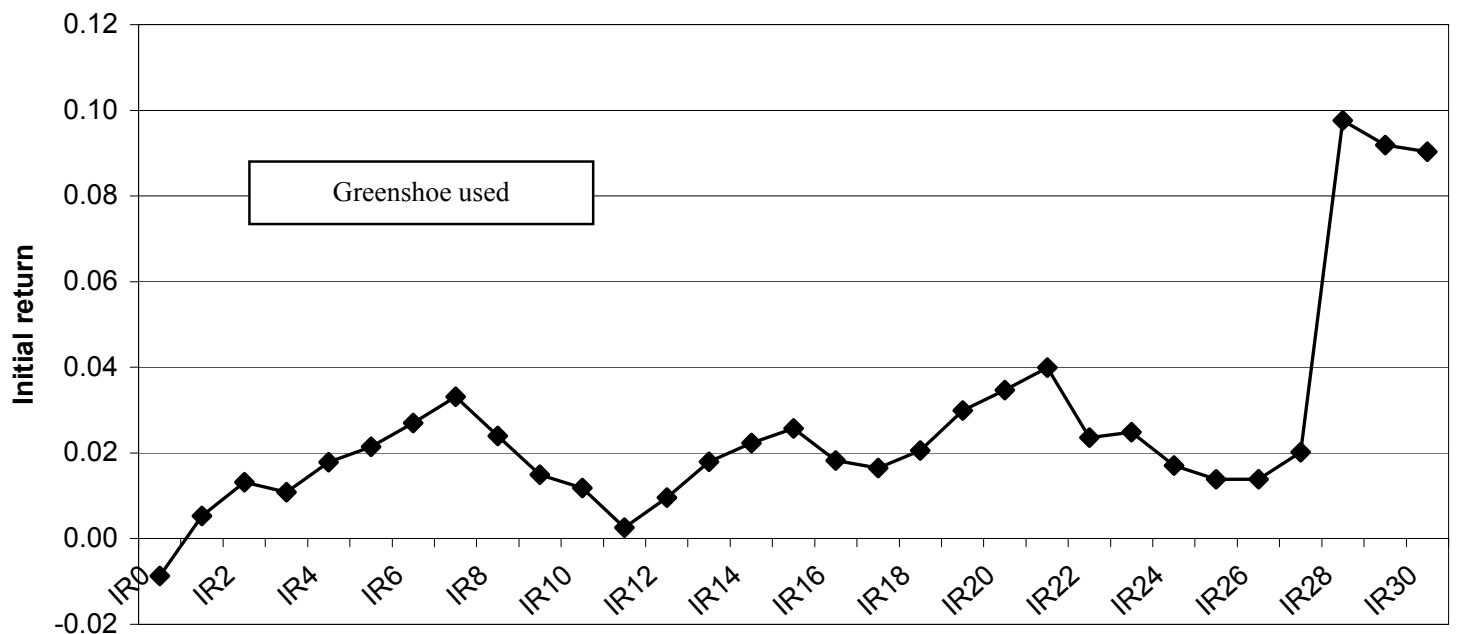

Holding period 


\section{Table VIII}

\section{OLS-and Tobin-regression of underpricing}

The sample covers the 1997 - 2001 period and 410 firm. The initial public offerings were taken from the Frankfurt Stock Exchange web pages and Factbooks and always double checked with the company's prospectus, homepage or investor relations department, the IPO database of the 'Börsenzeitung' and the IPO database of OnVista. Initial return $(I R 1)$ is calculated as ln $\left(\mathrm{P}_{t} / \mathrm{P}_{\text {offer }}\right)$, where $\mathrm{P}_{\mathrm{t}}$ is the first day closing price and $\mathrm{P}_{\text {offer }}$ the offer price after the bookbuilding period. Bbd (bookbuilding days) is calculated as the difference between start and end of the subscription period. Age is calculated as the difference between the foundation of the company and the IPO. If the firm has gone through mergers or restructuring prior going public, the foundation date of the oldest predecessor has been chosen. The width of the bookbuilding range ( $b b w)$ represents the difference between the upper and lower bound divided by the midpoint The inverse of the total amount of shares at the issue date multiplied by the issue price yields the variable marketcap. Volume represents the total number of IPOs 30 days prior to the issue date. The dummy variable greenshoe takes the value one if the total greenshoe has been used after the IPO and zero otherwise. Bc is the business climate index from the OECD statistics during the last month (i.e. $30 / 31$ days). Nemax is calculated as the holding period return of the Nemax All Share index during the last 30 trading days prior to the IPO. Underwriter 1 and underwriter 2 are dummy variables based on a ranking which divides the underwriter, according the total number of accompanied IPOs, into three quantiles. The variable underwriter 1 and underwriter 2 is coded one if the underwriter belongs to the highest or second quantile, respectively, and zero otherwise. $S d$ is the standard deviation of aftermarket closing prices divided by the issue price. All variables excluding the dummies, nemax and $b c$ are transformed by the natural logarithm. The Models are estimated using OLS, adjusted by White's (1980) standard errors, and censored data estimation (Tobin). The results of the t-statistics (twosided test) are denoted in brackets. The reported F-statistic stands for the significance of the proposed model. We use ***,**, and * to denote significance at the one percent, five percent and ten percent level, respectively.

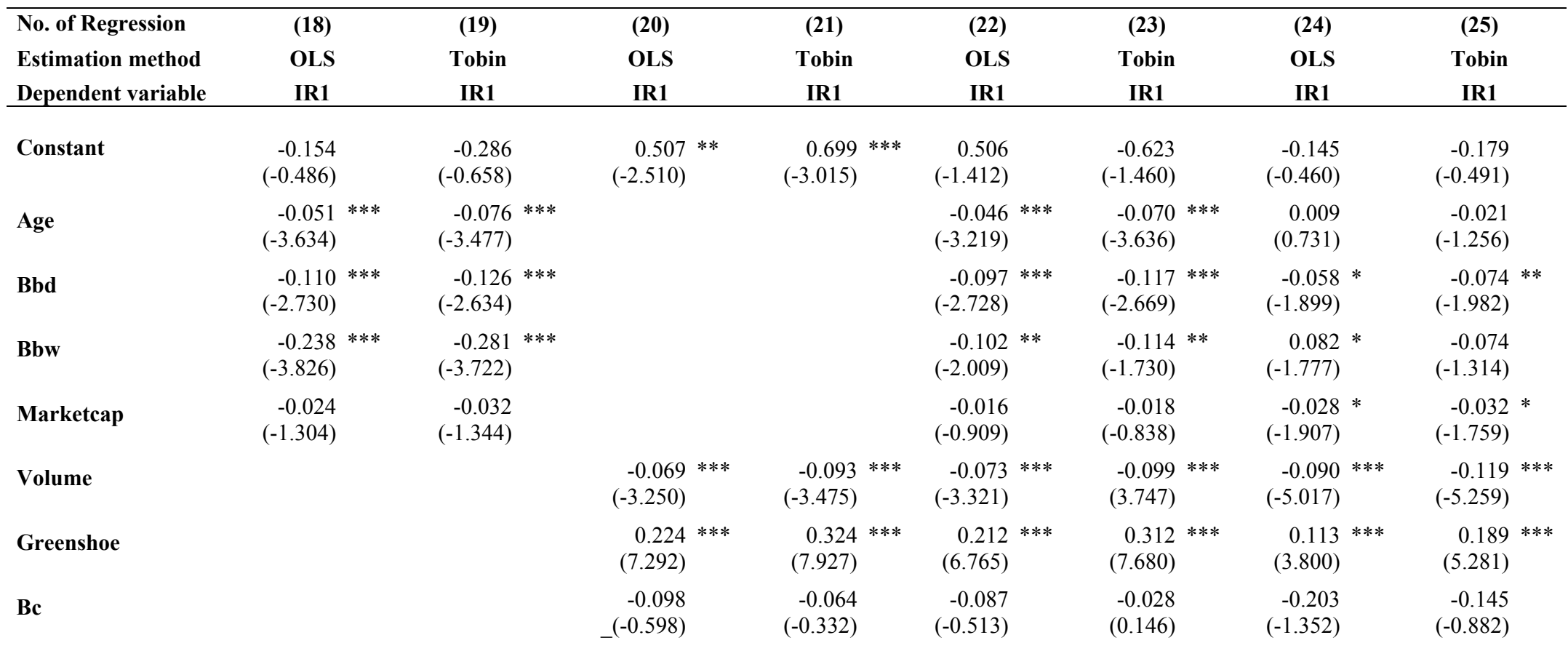




\begin{tabular}{|c|c|c|c|c|c|c|c|}
\hline Nemax & & $\begin{array}{l}0.922 * * * \\
(8.273)\end{array}$ & $\begin{array}{l}1.025 * * * \\
(8.973)\end{array}$ & $\begin{array}{l}0.8644^{* * *} \\
(7.712)\end{array}$ & $\begin{array}{l}0.9544^{* * *} \\
(8.515)\end{array}$ & $\begin{array}{l}0.696 \text { *** } \\
(7.429)\end{array}$ & $\begin{array}{l}0.732 * * * \\
(7.597)\end{array}$ \\
\hline Underwriter1 & & $\begin{array}{r}-0.004 \\
(-0.088)\end{array}$ & $\begin{array}{r}-0.016 \\
(-0.296)\end{array}$ & $\begin{array}{r}-0.035 \\
(-0.766)\end{array}$ & $\begin{array}{r}-0.051 \\
(0.918)\end{array}$ & $\begin{array}{r}0.063 \\
(-1.615)\end{array}$ & $\begin{array}{c}-0.087 \\
(-1.823)\end{array}$ \\
\hline Underwriter2 & & $\begin{array}{r}-0.011 \\
(-0.211)\end{array}$ & $\begin{array}{r}0.010 \\
(0.163)\end{array}$ & $\begin{array}{r}-0.041 \\
(-0.824)\end{array}$ & $\begin{array}{r}0.028 \\
(0.464)\end{array}$ & $\begin{array}{r}-0.073 \\
(-1.735)\end{array}$ & $\begin{array}{r}-0.070 \\
(-1.373)\end{array}$ \\
\hline Sd & & & & & & $\begin{array}{l}0.188 \text { *** } \\
(8.627)\end{array}$ & $\begin{array}{l}0.216^{* * *} \\
(11.493)^{-10}\end{array}$ \\
\hline F-statistic & $9.288 * * *$ & $30.041 * * *$ & & $21.355 * * *$ & & $38.122 * * *$ & \\
\hline $\mathbf{R}^{2}$ (adjusted) & 0.075 & 0.299 & & 0.333 & & 0.500 & \\
\hline Sample size & 410 & 409 & 409 & 409 & 409 & 409 & 409 \\
\hline
\end{tabular}

